Article

\title{
Effects of Seasonal Variability on the Physicochemical, Biochemical, and Nutritional Composition of Western Peninsular Malaysia Gracilaria manilaensis
}

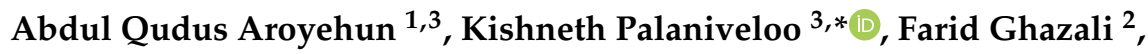 \\ Mohammed Rizman-Idid ${ }^{3}$ and Shariza Abdul Razak ${ }^{1, *}$ \\ 1 Nutrition and Dietetics Program, School of Health Sciences, Health Campus. Universiti Sains Malaysia, \\ Kubang Kerian 16150, Kelantan, Malaysia \\ 2 Biomedicine Program, School of Health Sciences, Health Campus. Universiti Sains Malaysia, \\ Kubang Kerian 16150, Kelantan, Malaysia \\ 3 Institute of Ocean and Earth Sciences, University of Malaya, Jalan Universiti, Kuala Lumpur 50603, \\ Wilayah Persekutuan Kuala Lumpur, Malaysia \\ * Correspondence: kishneth@um.edu.my (K.P.); shariza@usm.my (S.A.R.); \\ Tel.: +603-79694640 (K.P.); +6019-964-4043 (S.A.R.)
}

Academic Editor: Adam Figiel

Received: 18 August 2019; Accepted: 3 September 2019; Published: 10 September 2019

\begin{abstract}
This study evaluated the effect of seasonal variation on the physicochemical, biochemical, and nutritional composition of Gracilaria manilaensis. Sampling was designed during the main monsoon seasons in Malaysia — the Southwest monsoon (SWM) and Northeast monsoon (NEM) — to understand the intraspecific variation $(p<0.05)$. Carbohydrates, protein, and dietary fiber were found to be higher in NEM-G. manilaensis, whereas a higher ash content was quantified in SWM-G. manilaensis. No significant differences were found in crude lipid and moisture content $(p>0.05)$. Vitamin B2 was calculated as $\left(0.29 \pm 0.06 \mathrm{mg} 100 \mathrm{~g}^{-1}\right)$ and $\left(0.38 \pm 0.06 \mathrm{mg} 100 \mathrm{~g}^{-1}\right)$ for the NEM and SWM samples, respectively $(p<0.05)$. The fatty acid profile showed the dominance of saturated fatty acids (SFAs) - palmitic acids, stearic acid, and myristic acid-while the mineral contents were found to be good sources of calcium (1750.97-4047.74 mg $100 \mathrm{~g}^{-1}$ ) and iron (1512.55-1346.05 mg $100 \mathrm{~g}^{-1}$ ). Tryptophan and lysine were recorded as the limiting essential amino acids (EAAs) in NEM G. manilaensis, while leucine and phenylalanine were found to be the limiting EAAs in the SWM samples. None of the extracts exhibited antibacterial properties against the screened strains. The study concluded that seasonal changes have a great effect on the biochemical composition of G. manilaensis.
\end{abstract}

Keywords: Gracilaria manilaensis; seasonal variation; physicochemical properties; nutritional properties; mineral elements; anti-microbial; heavy metals

\section{Introduction}

Food security is a global concern due to the increasing human population amid dwindling natural resources in a fragile natural environment [1]. An estimated 1 billion people currently suffer from malnutrition due to insufficient dietary energy, accessibility, and micronutrient undernourishment [2,3]. However, in a renewed interest to exploit new resources to meet the growing demand for food and value-added nutritional ingredients, marine macroalgae (commonly referred to as seaweed) seem to meet the requirements [4].

The red seaweed, phylum Rhodophyta, is abundant, with nearly 6000 species globally [5]. The genus Gracilaria Greville (Gracilariales, Rhodophyta) is the second-largest commercially important agarophyte with 160 taxonomically accepted species found distributed in tropical climates and temperate regions [6,7]. It is an important source of food and agar, exceeding the capacity of the genus 
Porphyra, Gelidium, and Pterocladia due to its tolerance to a wide range of environmental conditions [8]. Gracilaria species is a benthic flora, existing in a diverse range of forms with a majority inhabiting the intertidal and subtidal zones in depths of $0.5 \mathrm{~m}$ and $10 \mathrm{~m}$ [9]. However, many species are still poorly known and have very limited distribution globally [10].

Seaweed contains essential macro- as well as micronutrients, consisting of high-quality protein, dietary fiber, vitamins, minerals, phytochemicals, and lipid content rich in mono and polyunsaturated fatty acids (PUFAs), which offer protection against different neurodegenerative pathologies [11]. Seaweed is an important food component in traditional Japanese, Chinese, South Korean, and Filipino cuisines [12]. Brown algae is the most consumed (66.5\%), followed by red algae (33\%) and green algae (5\%) [13]; however, global commercial production is low.

Seaweed is consumed as both raw or processed food [14]. However, in Western countries, raw consumption is recent due to it being culturally consumed for its polysaccharides (carrageenans, agars, and alginates)—as a stabilizer, additive, and gelling and thickening agent [15]. The polysaccharides in red seaweed contain high agarose content made of polymers with D-galactose and 3,6-anhydro-L-galactopyranose subunits, which are crucial for biofuel bioconversion [16]. Seaweeds occur in abundance along the Malaysian coasts. However, seaweed horticulture is exclusive to Sabah, mainly off the coast of Semporna, Kudat, Kunak, and Lahad Datu [17]. Currently, there is an emphasis on the production of red seaweed and development of new products with keen interest in the genus Glacilaria. The abundance of Gracilaria spp. in Western Peninsular Malaysia and knowledge of their biochemical variations might offer useful information that is important to sustain the seaweed industry.

The genus Gracilaria is known for its low lipid content rich in PUFAs, as well as significant levels of essential amino acids (EAAs) and non-essential amino acids (NEAAs), making them highly favorable for human health [18-20] and comparable to other conventional protein sources, such as meat, eggs, cereal, soybean, and milk [21]. In addition to its vast nutritional properties, the genus Gracilaria is also known for polysaccharides, commonly referred to as dietary fiber that is not degraded by enzymes in the gastrointestinal tract [22]. Dietary fiber such as agar and carrageenans offer beneficial health outcomes, such as increasing the volume of fecal bulk and regulating cholesterol serum levels $[18,22,23]$. These physiological effects might be attributed to the hydrocolloid properties of seaweeds [24]. Interestingly, these properties propel the use of Gracilaria in food technology to produce low-calorie food products [25] that are relevant for weight control, as well as prevention of cardiovascular and gastrointestinal diseases [26,27].

The extensive coastline and numerous islands of Malaysia provide suitable habitats for the growth of diverse seaweed flora. A total of 24 species of Gracilaria have been recorded [28,29], and G. manilaensis is one of the most prolific agarophytes. Presently, G. manilaensis is the only species cultivated at Lumut, Perak, as feed for abalone [29] with annual production of 200 metric tonnes (Department of Fisheries Malaysia, 2018). Reports on the nutritional properties of Gracilaria spp. is mostly from East Malaysia [19]. However, there is no study on the effect of seasonal variations on the chemical and nutritional properties of $G$. manilaensis. To the best of our knowledge, only the fatty acids profile of G. manilaensis harvested from Kuala Muda, Kedah, has been reported [30] and investigations of its biological activities have shown promising antimicrobial, antioxidant, cytotoxic, and neuritogenic properties [31,32].

The chemical composition of seaweeds varies with species, maturity stage, sampling, and ecological conditions (habitat, temperature, and season), which could either stimulate or inhibit the biosynthesis of its nutrient composition [33]. The current study sought to examine the effects of seasonal variations on the biomass composition of the red macroalgae G. manilaensis collected from Western Peninsular, Malaysia. The proximate and nutritional composition was fully expounded to also assess its potential application as a food source. 


\section{Results}

\subsection{Chemical Composition of Seaweeds}

The seasonal variation in the proximate composition of G. manilaensis based on dry weight (w.w.) is summarized in Table 1 . The moisture content showed no statistical significant $(p>0.05)$ differences between the two seasons. However, the proximate composition showed significant difference between the NEM and SWM samples. In general, carbohydrates, dietary fiber, and crude protein contents were most abundant in the NEM-G. manilaensis sample, while ash content was significantly higher in the SWM sample. No significant differences were found in crude lipid content. For gross energy, G. manilensis collected in November displayed a higher value at $\left(2721.67 \pm 10.69 \mathrm{cal} \mathrm{g}^{-1}\right)$ than those harvested in August $\left(2348.33 \pm 9.87 \mathrm{cal} \mathrm{g}^{-1}\right)$.

Table 1. Variation in Proximate Composition (g $\left.100 \mathrm{~g}^{-1} \mathrm{DW}\right)$ and Gross Calorific Value (cal g ${ }^{-1}$ ) Of G. manilaensis Collected in Johor, Malaysia.

\begin{tabular}{|c|c|c|}
\hline Composition & $\begin{array}{c}\text { G. manilaensis } \\
\text { (NEM) }\end{array}$ & $\begin{array}{c}\text { G. manilaensis } \\
\text { (SWM) }\end{array}$ \\
\hline Moisture & $9.59 \pm 0.40$ & $9.06 \pm 0.10$ \\
\hline Ash & $30.26 \pm 0.13^{b}$ & $38.48 \pm 0.23^{a}$ \\
\hline Crude Lipids & $1.20 \pm 0.15$ & $1.13 \pm 0.18$ \\
\hline Crude Protein & $19.39 \pm 0.12^{\mathrm{a}}$ & $16.03 \pm 0.26^{b}$ \\
\hline Pure protein & $16.38 \pm 0.24^{\mathrm{a}}$ & $12.34 \pm 0.31^{b}$ \\
\hline NPN & $3.01 \pm 0.50$ & $3.69 \pm 0.11$ \\
\hline Carbohydrate & $39.56 \pm 0.26^{a}$ & $35.30 \pm 0.34^{b}$ \\
\hline Total Dietary Fiber & $31.07 \pm 1.08^{\mathrm{a}}$ & $22.16 \pm 0.11^{b}$ \\
\hline Caloric Value $\left(\mathrm{cal} \mathrm{g}^{-1}\right)$ & $2721.67 \pm 10.69^{a}$ & $2348.33 \pm 9.87^{b}$ \\
\hline
\end{tabular}

NEM, samples from Northeast Monsoon (Straits of Johor). SWM, samples from Southwest Monsoon (Straits of Johor). Results are expressed as Mean \pm SD $(n=3)$. Means with different superscripts $(a, b)$ within the same line were significantly different $(p<0.05)$.

\subsection{Fatty Acids Compositions}

The total fatty acid profile, expressed as $\mathrm{g}$ fatty acids methyl esters (FAME)/100 $\mathrm{g}$ total fat, for

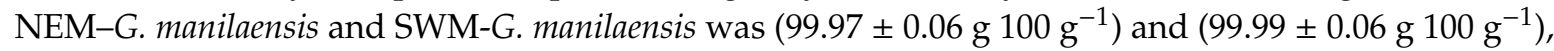
respectively (Table 2). The main SFAs of both NEM- and SWM-G. manilaensis were palmitic acid (C16:0), followed by stearic acid (C18:0), and myristic acid (C14:0). With respect to MUFAs, only

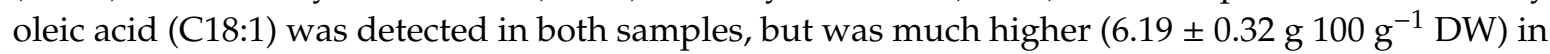
SWM-G. manilaensis. As for the PUFAs, a small fraction of eicosadienoic acid (C20:2) was noticed only in NEM-G. manilaensis. Overall, SFAs made up to $97.57 \mathrm{~g} 100 \mathrm{~g}^{-1} \mathrm{DW}$ of total fatty acids, followed by

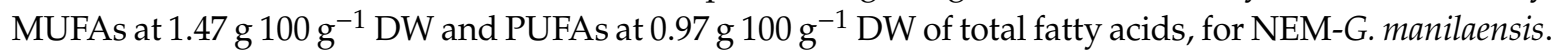

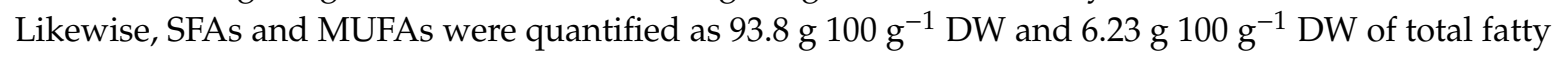
acids, respectively, in SWM-G. manilaensis.

Table 2. Variation in the Fatty Acid Composition (g Fatty Acid Methyl Esters/100 g Total Fat) of G. manilaensis.

\begin{tabular}{|c|c|c|}
\hline Fatty Acids (g $\left.100 \mathrm{~g}^{-1} \mathrm{DW}\right)$ & G. manilaenisis (NEM) & G. manilaensis (SWM) \\
\hline \multicolumn{3}{|c|}{ SFAs } \\
\hline Myristic acid (C14:0) & $2.6^{b}$ & $3.73 \pm 0.06^{\mathrm{a}}$ \\
\hline Pentadecanoic acid (C15:0) & 0.9 & ND \\
\hline Palmitic acid (C16:0) & $89.27 \pm 0.21^{a}$ & $83.87 \pm 0.64^{b}$ \\
\hline Heptadecanoic acid (C17:0) & $0.77 \pm 0.06$ & ND \\
\hline Stearic acid (C18:0) & $3.97 \pm 0.06^{b}$ & $6.2 \pm 0.7^{\mathrm{a}}$ \\
\hline Total & $97.5 \pm 0.05^{\mathrm{a}}$ & $93.8 \pm 0.15^{b}$ \\
\hline$\%$ of SFA in total FAs & $97.57 \pm 0.05^{\mathrm{a}}$ & $93.8 \pm 0.03^{b}$ \\
\hline
\end{tabular}


Table 2. Cont.

\begin{tabular}{ccc}
\hline Fatty Acids $\left(\mathbf{g} \mathbf{1 0 0} \mathbf{~ g}^{-1}\right.$ DW) & G. manilaenisis (NEM) & G. manilaensis (SWM) \\
\hline & MUFAs & \\
\hline Oleic acid (C18:1 $\boldsymbol{\omega}_{\mathbf{9}}$ cis) & $1.47 \pm 0.06^{\mathrm{b}}$ & $6.19 \pm 0.32^{\mathrm{a}}$ \\
\% of MUFAs in total FAs & $1.47 \pm 0.03^{\mathrm{b}}$ & $6.19 \pm 0.18^{\mathrm{a}}$ \\
\hline & PUFAs & \\
\hline Eicosadienoic acid (C20:2 $\mathbf{\Delta 1 1 , 1 4 )}$ & $0.97 \pm 0.06$ & $\mathrm{ND}$ \\
\% of PUFAs in total FAs & $0.97 \pm 0.03$ & - \\
Total fatty acids & $99.97 \pm 0.06$ & $99.99 \pm 0.06$ \\
\hline
\end{tabular}

Mean \pm standard deviation of three replicates. Different lowercase letters within the same row indicate statistical differences between groups $(p<0.05)$. "ND" indicates "not detected"; polyunsaturated fatty acids (PUFA); monounsaturated fatty acids (MUFA); saturated fatty acids (SFA).

\subsection{Amino Acids Compositions}

The seasonal variation in the amino acids (AAs) composition of G. manilaensis is summarized in Table 3. The total AAs content in the NEM and SWM samples were $\left(16.36 \pm 1.31 \mathrm{~g}^{100 \mathrm{~g}^{-1}}\right.$ $\mathrm{DW})$ and $\left(12.24 \pm 1.26 \mathrm{~g} 100 \mathrm{~g}^{-1} \mathrm{DW}\right)$, respectively $(p<0.05)$. No significant difference was found in the non-protein nitrogenous (NPN) fraction between the NEM and SWM samples (Table 1). This showed that the NPN-fraction of G. manilaensis, comprising of nucleic acids, nitrate, nitrite, ammonium compounds, chlorophyll, and phycoerythrine, as well as free AA, was negligible [19,34]. All the nine essential amino acids (EAAs) and non-essential amino acids (NEAAs) were found in NEM-G. manilaenisis. The results differed for SWM-G. manilaensis, which presented only six EAAs and eight NEAAs. Similarly, the total EAAs for NEM samples was higher $\left(2840.20 \pm 0.31 \mathrm{mg}^{\left.-100 \mathrm{~g}^{-1} \mathrm{DW}\right)}\right.$ than those $\left(665.02 \pm 0.07 \mathrm{mg} 100 \mathrm{~g}^{-1} \mathrm{DW}\right)$ obtained from the SWM samples $(p<0.05)$. Furthermore, total NEAAs was found to be higher for NEM-G. manilaensis (13517.96 $\left.\pm 1.13 \mathrm{mg} 100 \mathrm{~g}^{-1} \mathrm{DW}\right)$ than

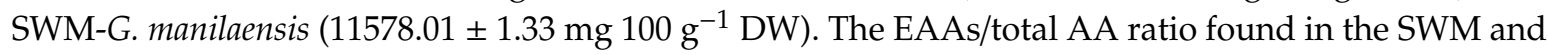

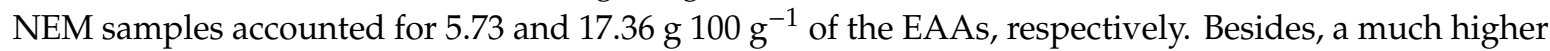

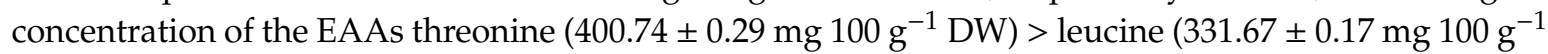

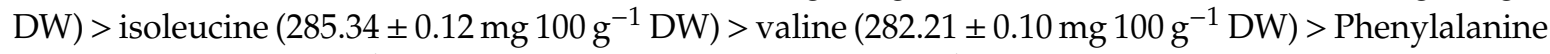

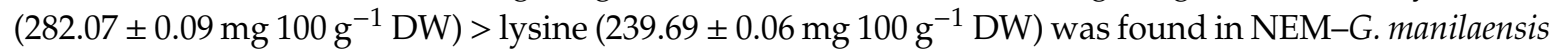
than in the SWM sample. In the NEAAs fraction, glutamic and aspartic acids were most abundant,

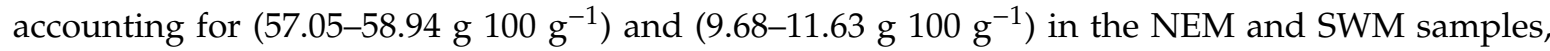
respectively. Further observations also indicated variation in NEAA composition, as the NEM samples contain seven AAs in the order of arginine $>$ tyrosine $>$ alanine $>$ serine $>$ glycine $>$ cysteine $>$ proline. In contrast, five were obtained from the SWM samples in descending order alanine $>$ arginine $>$ serine $>$ glycine $>$ tyrosine $>$ proline.

Table 3. Variation in the Amino Acids Composition (mg $\left.100 \mathrm{~g}^{-1} \mathrm{DW}\right)$ of G. manilaensis.

\begin{tabular}{|c|c|c|c|c|c|}
\hline Amino acids & $\begin{array}{c}\text { G. manilaensis } \\
\text { (NEM) }\end{array}$ & $\begin{array}{c}\mathrm{mg} \mathrm{g}^{-1} \\
\text { Protein/(AA } \\
\text { Score }\left(\mathrm{g} 100 \mathrm{~g}^{-1}\right)\end{array}$ & $\begin{array}{c}\text { G. manilaensis } \\
\text { (SWM) }\end{array}$ & $\begin{array}{c}\operatorname{mg~} 100 \mathrm{~g}^{-1} \\
\text { Protein/AA } \\
\text { Score }\left(\mathrm{g} 100 \mathrm{~g}^{-1}\right)\end{array}$ & $\begin{array}{c}\text { FAO/WHO/UNU } \\
(2007)\end{array}$ \\
\hline \multicolumn{6}{|l|}{$\begin{array}{l}\text { Essential Amino } \\
\text { acids }\end{array}$} \\
\hline Histidine (His) & $620.98 \pm 0.23$ & $32.03(200.16)$ & ND & ND & 16 \\
\hline Threonine (Thr) & $400.74 \pm 0.29^{a}$ & $20.67(82.67)$ & $231.73 \pm 8.66^{b}$ & $14.46(90.35)$ & 25 \\
\hline Methionine (Met) & $393.13 \pm 0.16$ & $20.28(88.15)$ & ND & ND & 23 \\
\hline Tryptophan (Try) & $4.37 \pm 0.02$ & $0.2254^{*}(3.22)$ & ND & ND & 7 \\
\hline Phenylalanine (Phe) & $282.07 \pm 0.09^{a}$ & $14.55(35.48)$ & $85.85 \pm 2.35^{b}$ & $5.36(13.06)$ & 41 \\
\hline Isoleucine (Ile) & $285.34 \pm 0.12^{\mathrm{a}}$ & $14.72(49.05)$ & $62.90 \pm 4.30^{b}$ & $3.92(13.08)$ & 30 \\
\hline Leucine (Leu) & $331.67 \pm 0.17^{a}$ & $17.19(28.04)$ & $58.51 \pm 1.99^{b}$ & $3.65(5.98)$ & 61 \\
\hline Lysine (Lys) & $239.69 \pm 0.06^{\mathrm{a}}$ & $12.36(25.75)$ & $129.62 \pm 6.45^{b}$ & $8.09(16.85)$ & 48 \\
\hline
\end{tabular}


Table 3. Cont

\begin{tabular}{|c|c|c|c|c|c|}
\hline Amino acids & $\begin{array}{c}\text { G. manilaensis } \\
\text { (NEM) }\end{array}$ & $\begin{array}{c}\mathrm{mg} \mathrm{g}^{-1} \\
\text { Protein/(AA } \\
\text { Score }\left(\mathrm{g} 100 \mathrm{~g}^{-1}\right)\end{array}$ & $\begin{array}{c}\text { G. manilaensis } \\
\text { (SWM) }\end{array}$ & $\begin{array}{c}\text { mg } 100 \mathrm{~g}^{-1} \\
\text { Protein/AA } \\
\text { Score }\left(\mathrm{g} 100 \mathrm{~g}^{-1}\right)\end{array}$ & $\begin{array}{c}\text { FAO/WHO/UNU } \\
\text { (2007) }\end{array}$ \\
\hline \multicolumn{6}{|l|}{ Non-essential acids } \\
\hline Aspartic acid (Asp) & $9640.82 \pm 0.22^{a}$ & & $6984.12 \pm 0.18^{b}$ & & \\
\hline Glutamic acid (Glu) & $1583.21 \pm 0.54^{\mathrm{a}}$ & & $1423.74 \pm 1.10^{b}$ & & \\
\hline Asparagine (Asn) & ND & & ND & & \\
\hline Serine (Ser) & $304.44 \pm 0.18^{\mathrm{a}}$ & & $289.97 \pm 0.16^{b}$ & & \\
\hline Glutamine (Gln) & ND & & ND & & \\
\hline Glycine (Gly) & $216.77 \pm 0.06^{b}$ & & $364.15 \pm 0.11^{\mathrm{a}}$ & & \\
\hline Arginine (Arg) & $573.41 \pm 0.27^{b}$ & & $830.29 \pm 0.15^{a}$ & & \\
\hline Alanine (Ala) & $314.29 \pm 0.18^{b}$ & & $1366.05 \pm 0.12^{a}$ & & \\
\hline Tyrosine (Tyr) & $499.26 \pm 0.22^{a}$ & & $196.47 \pm 0.15^{b}$ & & \\
\hline Cysteine (Cys) & $200.82 \pm 0.33$ & & ND & & \\
\hline Proline (Pro) & $185.14 \pm 0.09^{\mathrm{a}}$ & & $123.23 \pm 0.03^{b}$ & & \\
\hline$\sum \sum$ NEAA & $13517.96 \pm 1.13^{\mathrm{a}}$ & & $11578.01 \pm 1.33^{b}$ & & \\
\hline$\sum \mathbf{A A}$ & $16358.37 \pm 1.31^{\mathrm{a}}$ & & $12243.04 \pm 1.26^{b}$ & & \\
\hline EAAs/Total AA & $0.17 \pm 0.14^{\mathrm{a}}$ & & $0.05 \pm 0.12^{b}$ & & \\
\hline $\begin{array}{c}\sum \text { EAAs/Total } \\
\text { AAs(\%) }\end{array}$ & $17.36 \pm 0.14^{a}$ & & $5.43 \pm 0.12^{b}$ & & \\
\hline$\sum$ EAAs/ $/ \sum$ NEAAs & $0.2101 \pm 0.0021^{\mathrm{a}}$ & & $0.0573 \pm 0.0011^{b}$ & & \\
\hline
\end{tabular}

The FAO requirement protein pattern referenced is amino acid scoring pattern for use in schoolchild/adolescent (3-10) year of age (WHO/FAO/UNU 2007). $\Sigma$ AA = Total Amino acids. (mean \pm standard deviation values) $(\mathrm{n}=3)$. expressed as $\mathrm{mg} / \mathrm{g}$ seaweed on a dry weight basis. * EAAs: Essential amino acids; NEAAs: Non-essential amino acids. $a, b$ values with different superscripts within the same line are significantly different.

\subsection{Mineral Composition}

The mineral concentration of the 16 elements (mg $100 \mathrm{~g}^{-1}$ dry wt.) analyzed in G. manilaensis is shown in Table 4. ICP-MS analysis detected significant levels of macroelements in the order of Ca

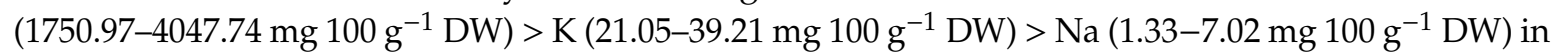
G. manilaensis $(p<0.05)$. Seaweed contains higher $\mathrm{Na}$ and $\mathrm{K}$ concentrations, but a low $\mathrm{Na} / \mathrm{K}$ ratio [35]. However, the $\mathrm{Na}\left(1.33-7.02 \mathrm{mg} 100^{-1} \mathrm{DW}\right)$ and $\mathrm{K}\left(21.05-39.21 \mathrm{mg} 100^{-1} \mathrm{DW}\right)$ of G. manilaensis were significantly low in the samples analyzed. The $\mathrm{Na}^{+} / \mathrm{K}^{+}$ratio of $G$. manilaensis $(0.03$ and 0.33$)$ conforms to the WHO dietary recommendation. Moreover, the total macroelement concentration noticed in the

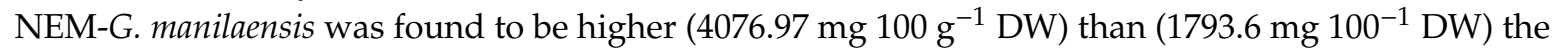

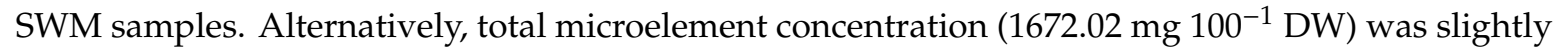

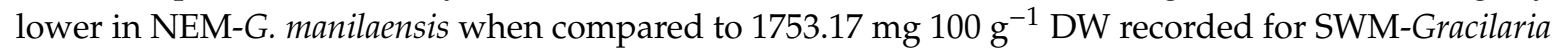
spp. The order of trace elements in NEM-G. manilaensis were $(\mathrm{Fe}>\mathrm{Mn}>\mathrm{Zn}>\mathrm{Cu}>\mathrm{Cr}>\mathrm{Co}>$ $\mathrm{Mo}>\mathrm{Se}$ ). As for the SWM samples, trace elements occurred in the order of $\mathrm{Fe}>\mathrm{Mn}>\mathrm{Zn}>\mathrm{Cu}>$ $\mathrm{Co}>\mathrm{Cr}>\mathrm{Se}>\mathrm{Mo}$. Fe (1512.55 mg $\left.100 \mathrm{~g}^{-1} \mathrm{DW}\right)$ and $\mathrm{Zn}\left(16.40 \mathrm{mg} 100^{-1} \mathrm{DW}\right)$ were found to be higher in NEM-G. manilaenisis. In contrast (401.81 mg $\left.100 \mathrm{~g}^{-1} \mathrm{DW}\right), \mathrm{Mn}$ was found to be higher in SWM-G. manilaensis. Assessment of heavy metals shows $\mathrm{Al}, \mathrm{Pb}, \mathrm{As}$, and $\mathrm{Cd}$ varied widely between

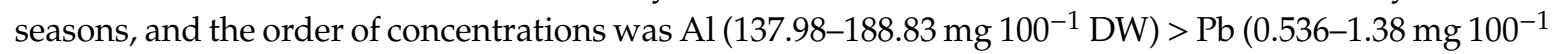

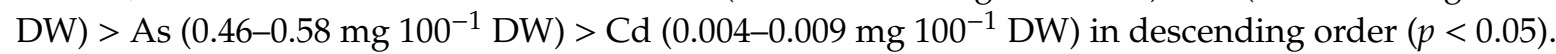
Considering $\mathrm{FAO} / \mathrm{WHO}$ dietary guidelines, the concentration of $\mathrm{Al}$ and $\mathrm{Pb}$ might be toxic and therefore, to minimize exposure from dietary consumption, G. manilaensis can be subjected to depurination to eliminate any form of impurity. 
Table 4. Seasonal Variation in the Mineral Composition ( $\mathrm{mg} 100 \mathrm{~g}^{-1} \mathrm{DW}$ ) of Edible G. manilaensis as Compared With the Dietary Reference Intake Values (RNI) $\left(8 \mathrm{~g} \mathrm{Day}^{-1}\right)$ of Australia.

\begin{tabular}{|c|c|c|c|}
\hline 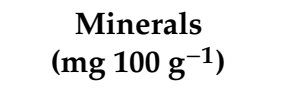 & G. manilaensis (NEM) & G. manilaensis (SWM) & Australia (RDIs) \\
\hline \multicolumn{4}{|l|}{ Macro Metals } \\
\hline Calcium (Ca) & $4047.74(32.38)$ & $1750.97(14.01)$ & 1000 mg/day \\
\hline Magnesium (mg) & $1.16(0.023)$ & $2.09(0.042)$ & $400 \mathrm{mg} /$ day \\
\hline Potassium (K) & $21.05(0.06)$ & $39.21(0.11)$ & $2.8 \& 3.8 \mathrm{~g} /$ day AI \\
\hline Sodium $(\mathrm{Na})$ & $7.02(0.02)$ & $1.33(0.01)$ & 2.3 g/day UL \\
\hline $\mathrm{Na} / \mathrm{K}$ & 0.33 & 0.03 & $<0.49$ \\
\hline Total & 4076.97 & 1793.60 & \\
\hline \multicolumn{4}{|l|}{ Trace Metals } \\
\hline Copper $(\mathrm{Cu})$ & $0.31(0.25)$ & $0.39(0.31)$ & 10 mg/day UL \\
\hline Iron $(\mathrm{Fe})$ & $1512.55(672.24)$ & $1346.05(598.24)$ & 8-18 mg/day \\
\hline Manganese (Mn) & $142.34(207040)$ & $401.81(584455)$ & $5.0 \& 5.5 \mu \mathrm{g} /$ day AI \\
\hline Molybdenum (Mo) & $0.05(8.89)$ & $0.03(5.33)$ & $0.045 \mathrm{mg} /$ day \\
\hline Selenium (Se) & $0.048(5.5)$ & $0.057(6.2)$ & $60 \& 70 \mu \mathrm{g} /$ day \\
\hline Zinc $(\mathrm{Zn})$ & $16.40(9.4)$ & $4.42(2.5)$ & $0.8 \& 14$ mg/day \\
\hline Chromium (Cr) & $0.26(59.44)$ & $0.19(43.43)$ & $25 \& 35 \mu \mathrm{g} /$ day AI \\
\hline Cobalt (Co) & 0.06 & 0.22 & \\
\hline Total & 1672.02 & 1753.17 & \\
\hline $\begin{array}{c}\text { Heavy Metal/ } \\
\text { EDIs }\left(\mathrm{g} 100 \mathrm{~g}^{-1}\right)\end{array}$ & & & WHO/FAO TWIs \\
\hline Arsenic (As) & $0.46(38.33)$ & $0.58(48.33)$ & $15 \mu \mathrm{g} / \mathrm{kg} \mathrm{BW}$ \\
\hline Cadmium (Cd) & $0.004(0.71)$ & $0.009(1.61)$ & $7 \mu \mathrm{g} / \mathrm{kg} \mathrm{BW}$ \\
\hline Aluminium (Al) & $188.83 *(236.04)$ & $137.98^{*}(172.48)$ & $1000 \mu \mathrm{g} / \mathrm{d}$ body BW \\
\hline Lead $(\mathrm{Pb})$ & $1.38(69)$ & $0.536(26.8)$ & $25 \mu \mathrm{g} / \mathrm{kg} \mathrm{BW}$ \\
\hline
\end{tabular}

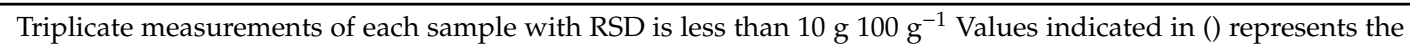
approximate \% of estimated daily intakes (EDIs) in comparison to the Recommended Dietary Allowances (RDA) [36]. Method Detection Limit (MDL). Nutrient reference values for Australia and New Zealand for men and women (Australia New Zealand Food Authority, 2005). Recommended Daily Intake (RDI); Tolerable Upper Intake Level (UL); Adequate Intake (AI); Body Weight (BW), provisional tolerable weekly intakes (PTWIs) (FAO/ WHO, 2011).

\subsection{Vitamin Composition $\left(m g g^{-1}\right)$, and Chlorophyll Content $\left(\mu g g^{-1}\right)$.}

The concentration of vitamins and chlorophyll contents is shown in Table 5. In this study, vitamin B2 (riboflavin) was $0.29 \pm 0.06 \mathrm{mg} \mathrm{g}^{-1}$ and $0.38 \pm 0.06 \mathrm{mg} \mathrm{g}^{-1}$ for NEM- G. manilaensis and SWM-G. manilaensis, respectively $(p<0.05)$. The methanolic extracts for NEM-G. manilaensis presented higher chlorophyll a $\left(9.57 \pm 0.01 \mu \mathrm{g} \mathrm{g}^{-1}\right)$ and chlorophyll b $\left(5.54 \pm 0.02^{\prime} \mu^{\mathrm{g} \mathrm{g}^{-1}}\right)$ than SWM-G. manilaensis with chlorophyll a $\left(7.07 \pm 0.03 \mu \mathrm{g} \mathrm{g}^{-1}\right)$ and chlorophyll b $\left(4.26 \pm 0.02 \mu \mathrm{g} \mathrm{g}^{-1}\right)$.

Table 5. Variation in Vitamin Composition $\left(\mathrm{mg} \mathrm{g}^{-1} \mathrm{DW}\right)$, Chlorophyll A and B Content $\left(\mu \mathrm{g} \mathrm{g}^{-1} \mathrm{DW}\right)$ of G. manilaensis.

\begin{tabular}{|c|c|c|}
\hline $\begin{array}{c}\text { Composition } \\
\left(\mathrm{mg} 100 \mathrm{~g}^{-1} \mathrm{DW}\right)\end{array}$ & G. manilaensis (NWM) & G. manilaensis (SWM) \\
\hline Vitamin A $\left(\mathrm{IU} \mathrm{g}^{-1}\right)$ & Below detectable level $(<1)$ & $\mathrm{ND}(<1)$ \\
\hline Vitamin B1 & Below detectable level $(<1)$ & $\mathrm{ND}(<1)$ \\
\hline Vitamin B2 & $0.29 \pm 0.06$ & $0.38 \pm 0.06$ \\
\hline Vitamin D (mcg $\left.100 \mathrm{~g}^{-1}\right)$ & Below detectable level $(<5)$ & $\mathrm{ND}(<5)$ \\
\hline Chlorophyll a & $1.25 \pm 0.06^{\mathrm{a}}$ & $1.29 \pm 0.06^{b}$ \\
\hline Chlorophyll b & $9.57 \pm 0.01^{\mathrm{a}}$ & $7.07 \pm 0.03^{b}$ \\
\hline
\end{tabular}

Results are expressed as Mean \pm SD $(n=3)$. ${ }^{a, b}$ values with different superscripts within the same line are significantly different. 


\subsection{Physicochemical Properties}

Table 6 illustrates the swelling capacity (SWC), water-holding (WHC), and oil-holding capacity (OHC) of NEM-G. manilaensis and SWM-G. manilaensis. In this study, SWC and WHC were significantly increased ( $p<0.05$, one-way ANOVA, Post Hoc Test using Duncan) as temperatures increased from $25^{\circ} \mathrm{C}$ to $37^{\circ} \mathrm{C}$ due to increase in solubility of the fibers and protein presence in G. manilaensis. SWC for the NEM and SWM samples increased from $\left(7.15 \pm 0.57 \mathrm{~mL} \mathrm{~g}^{-1}\right.$ vs. $\left.7.92 \pm 0.98 \mathrm{~mL} \mathrm{~g}^{-1} \mathrm{DW}\right)$ at $25^{\circ} \mathrm{C}$ to $\left(9.80 \pm 0.06\right.$ vs. $\left.9.91 \pm 0.05 \mathrm{~mL} \mathrm{~g}^{-1} \mathrm{DW}\right)$ after incubation at $37^{\circ} \mathrm{C}(p<0.05)$. Similarly, WHC for the NEM and SWM-G. manilaensis also showed a significant increase from $(9.81 \pm 0.76$ vs. $9.94 \pm 0.67)$ at $25^{\circ} \mathrm{C}$ to $\left(11.89 \pm 0.37 \mathrm{~g} \mathrm{~g}^{-1} \mathrm{DW}\right.$ vs. $\left.11.07 \pm 0.57 \mathrm{~g} \mathrm{~g}^{-1} \mathrm{DW}\right)$ at $37^{\circ} \mathrm{C}$. The mean OHC for NEM-G. manilaensis $\left(1.97 \pm 0.20 \mathrm{~g}\right.$ oil g $\left.^{-1} \mathrm{DW}\right)$ was significantly higher than that for SWM-G. manilaensis $\left(1.59 \pm 0.21 \mathrm{~g}\right.$ oil g $\mathrm{g}^{-1}$ DW) $(p<0.05)$.

Table 6. Variation in The Physicochemical Properties of Edible G. manilaensis at $25^{\circ} \mathrm{C}$ and $37^{\circ} \mathrm{C}$.

\begin{tabular}{|c|c|c|c|c|c|}
\hline Seaweed & \multicolumn{2}{|c|}{$\operatorname{SWC}\left(\mathrm{mL} \mathrm{g}^{-1}\right)$} & \multicolumn{2}{|c|}{ WHC $\left(\mathrm{g} \mathrm{g}^{-1}\right)$} & $\frac{\mathrm{OHC}\left(\mathrm{g} \mathrm{g}^{-1}\right)}{25^{\circ} \mathrm{C}}$ \\
\hline G. manilaensis (NEM) & $7.15 \pm 0.57 \mathrm{bB}$ & $9.91 \pm 0.05^{\mathrm{aA}}$ & $9.81 \pm 0.76^{\mathrm{bB}}$ & $11.89 \pm 0.37^{\mathrm{aA}}$ & $1.97 \pm 0.20^{\mathrm{a}}$ \\
\hline G. manilaensis (SWM) & $7.92 \pm 0.98^{a B}$ & $9.80 \pm 0.06^{\mathrm{bA}}$ & $9.94 \pm 0.67^{\mathrm{aA}}$ & $11.07 \pm 0.57^{b B}$ & $1.59 \pm 0.21^{b}$ \\
\hline
\end{tabular}

Values are Mean $\pm S E M, n=2$ on DW. ${ }^{a, b}$ values with different superscripts within the same column are significantly different between seaweeds. ${ }^{\mathrm{A}, \mathrm{B}}$ values with different superscripts within the same line shows significant differences between temperatures.

\subsection{Antimicrobial Properties}

The antibacterial activity of the ethyl acetate extracts of G. manilaensis was done via standard disc diffusion assay against four pathogenic Gram-negative bacteria strains, including Pseudomonas aeriginosa, Klebsiella pneumoniae, Escherichia coli, and Salmonella serovar typhi, as well as two Gram-positive bacteria, strain Staphylococcus aureus and Bacillus subtilis, as described by Baur et al. [37]. However, in this experiment, all extract dilutions and their replicates were not able to inhibit the growth of bacteria.

\section{Discussion}

This study shows that the proximate and nutritional composition of G. manilensis changes according to seasons [38]. Being marine in nature, the moisture content of seaweed can reach up to

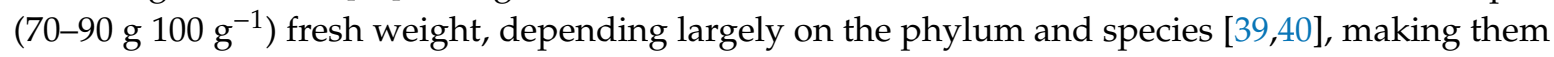
highly perishable in their fresh state a few days after harvesting. The drying process plays an important role in the preservation of seaweed products and could affect their nutritional value [41,42]. It helps reduce the water activity level, which retards microbial growth, thus ensuring the conservation of desirable qualities [43]. Similarly, in industries, drying is essential because crude extracts of wet seaweed do not gel [44]. The results obtained were similar to recent data found for G. corticata

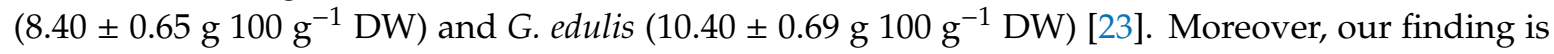
comparable to data reported by Lorenzo et al. [45], which observed the moisture content of different

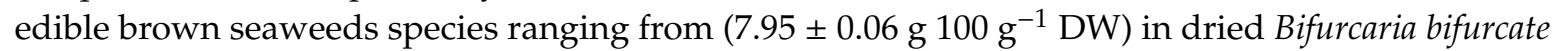

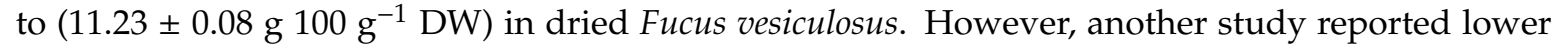
moisture content of $\left(5.32 \pm 0.10 \mathrm{~g} 100 \mathrm{~g}^{-1} \mathrm{DW}\right)$ for G. changii seaweed [19].

Crude ashes are inorganic constituents found in the cell sap of seaweed. They are an essential

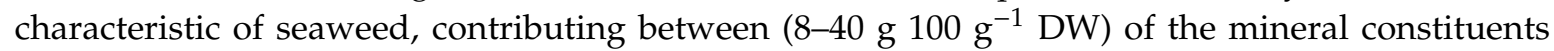
required for human and animal nutrition [46]. In this study, G. manilaensis was found to have a high percent of crude ash during the SWM in August, which is consistent with previous data that linked variation in the ash content of seaweeds to changes in environmental conditions and seasons [47-49]. Besides, the high crude ash content shows the presence of appreciable amounts of diverse minerals found in G. manilaensis. This result is also in agreement with data reported by Etemadian et al. [50],

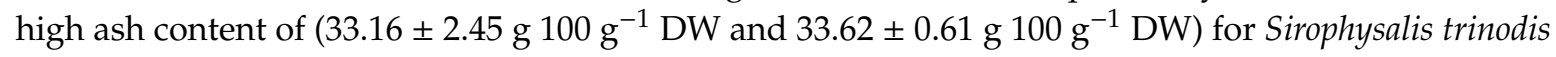


and Polycladia myrica, respectively.. Similarly, previous authors have also reported a higher ash content

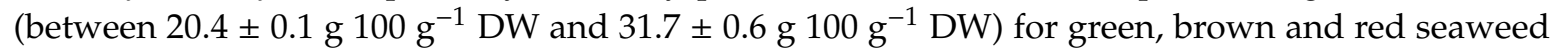
(aquaculture species) from Europe [51]. However, G. corticata and G. edulis contained a lower ash content $8.10 \pm 0.49 \% \mathrm{DW}$ and $7.36 \pm 0.39 \% \mathrm{DW}$, respectively [23]. Similarly, a lower ash content of $8.70 \%$ was reported for G. edulis [18]. The crude ash content found in seaweed is higher than the

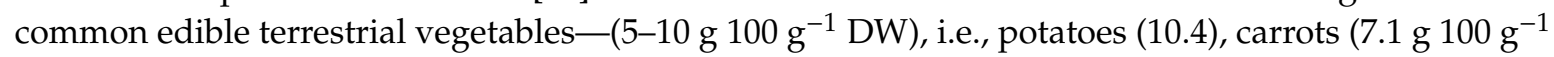
$\mathrm{DW})$, tomatoes (7.1 g $\left.100 \mathrm{~g}^{-1} \mathrm{DW}\right)$, and sweet corn (2.6 g $\left.100 \mathrm{~g}^{-1} \mathrm{DW}\right)$ [52], but comparable to the

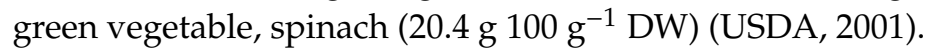

The majority of edible seaweeds have very low crude fat content $\left(0.3-7 \mathrm{~g} 100 \mathrm{~g}^{-1} \mathrm{DW}\right)$, revealing a low source of nutritional energy comparable with land vegetables [53]. The fat content, as observed in G. manilaensis, presented no statistical differences between the NEM and SWM season.

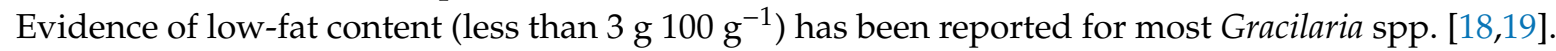
Marinho-Soriano et al. [54] reported a similar pattern wherein the lipids content of G. cervicornis did not vary significantly throughout the year of harvest. Alternatively, Benjama et al. [55] reported that

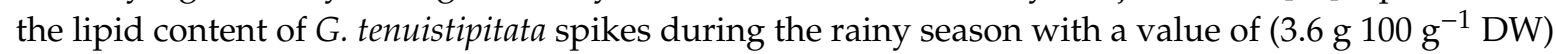
in December in contrast to G. fisheri, which had lower lipids content during the rainy season with a value of $1.7 \%$ in April. Those fluctuations are due to variations in environmental conditions such as temperature, salinity, and nutrients [56,57]. The crude lipids content presented for G. manilaensis

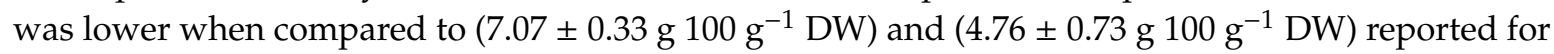

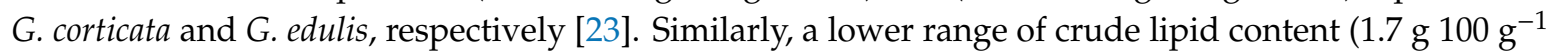
DW) and (3.6 $\left.100 \mathrm{~g}^{-1} \mathrm{DW}\right)$ was found for G. fisheri and G. tenuistipitata, respectively [55]. Interestingly,

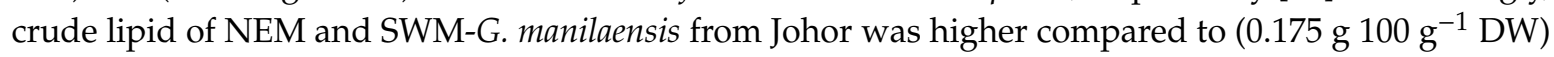
observed in G. manilaensis collected in Kedah [30]. Thus, fat content in Gracilaria can widely vary, depending on the source and species [23].

The phylum Rhodophyta contains high protein content (10-30 g $\left.100 \mathrm{~g}^{-1} \mathrm{DW}\right)$ [58] comparable to high-protein plant foods such as soybean and wheat [33]. In the present study, protein content showed highly significant differences $(p<0.05)$ for both samples. This result agreed with previous studies by Marinho et al. [54] and Benjama and Masniyom [59] on Graclaria spp., which describes that protein content varies depending on season and environment. A comparable trend demonstrating fluctuations in algal protein content was recorded for red seaweed Palmaria palmata [58], which showed a higher

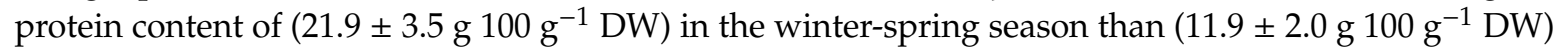
found in summer-early autumn. In this study, protein content for the NEM and SWM samples were

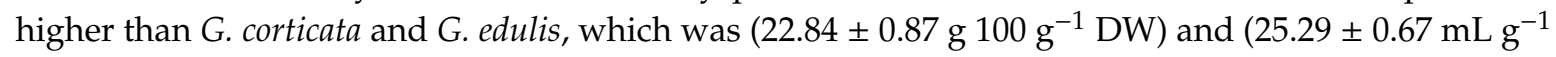

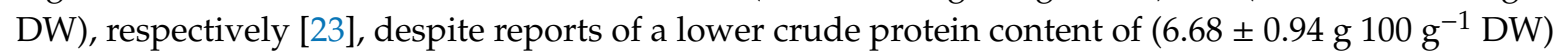

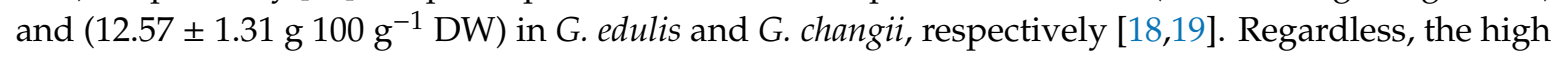
protein content recorded in G. manileansis suggests that it might be considered a potential marine plant source of protein $[54,55]$.

Plant carbohydrate content is often influenced by biomass, which suggests that macroalgal carbohydrate synthesis is related to periods of maximum growth, and increased in photosynthesis activity [9,54]. The total carbohydrate content of both the NEM and SWM samples was markedly

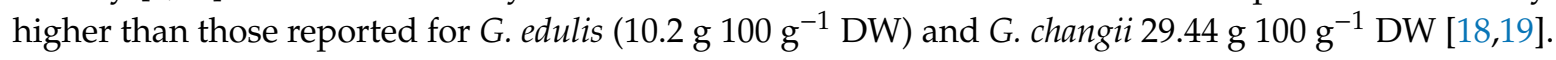
Other authors also found much lower carbohydrate content $8.30 \pm 1.89$ and $4.71 \pm 0.60$ in G. corticata and G. edulis, respectively. The fluctuations in the carbohydrate content of G. manilaensis might be due to the influence of factors such as temperature, salinity, and nutrient concentration $[9,60]$. Besides being an energy source, carbohydrate content is an important nutritive component of metabolic processes in seaweed [61].

Seaweeds contain a substantial quantity of polysaccharides, which comprise of soluble and insoluble dietary fibers [62]. In this study, G. manilaensis presented very high dietary fiber in both seasons. On the other hand, a lower dietary fiber content was found for G. edulis and G. acerosa, which

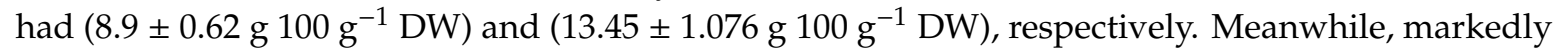




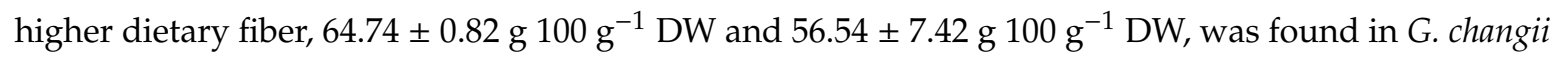
and G. cervicornis $[19,54]$. Dietary fiber plays a crucial role in the growth and protection of beneficial intestinal flora, which helps prevent the risks of colon cancer [34]. Overall, seaweeds contain relatively low energy density due to low crude lipid content, high protein content, as well as non-digestible polysaccharides [63]. Similarly, the gross caloric content of G. manilaensis was found to be low in both NEM and SWM samples.

Red seaweeds are predominantly rich in SFAs and PUFAs, which offer extensive nutritional applications in the food and feed, biotechnological, cosmetic, and pharmaceutical industries [26,64]. In this study, total fatty acids content was significantly higher than those obtained by previous authors,

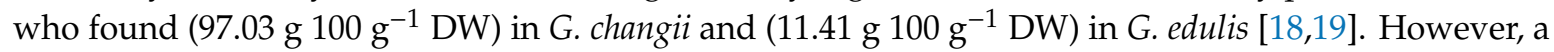
higher proportion was reported by Neto et al. [51], who found $117.15 \%$ in Gracialaria spp. A fatty acid profile revealed that the most abundant fatty acids in seaweeds are palmitic, followed by stearic acid, and myristic acid. A similar finding was reported for $G$. changii as the percentage of palmitic acid and

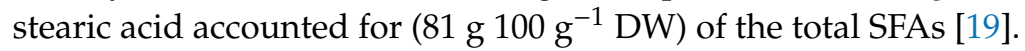

Other authors, including Khotimchenko et al. [65] and Bhaskar, Narayan et al. [64], also reported

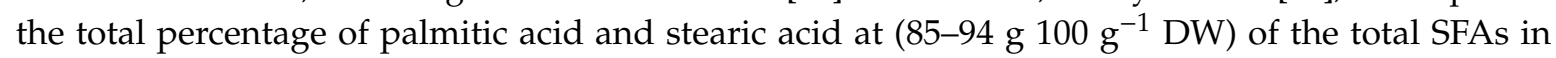
the genus Gracilaria spp. In contrast, pentadecanoic acid 5.12\% and palmitic acid (4.45 g $100 \mathrm{~g}^{-1}$ DW) was recorded as the dominant SFAs found in G. manilaensis [30]. In general, the presence of high palmitic acid (C16:0) composition is due to the distinct character traits of individual genera [66]. Overall, the G. manilaensis analyzed possesses a substantial quantity of SFAs and variation in content might be attributed to the influence of abiotic factors such as light, salinity, and nutrients; as well as seasonality $[57,66,67]$.

In the EAAs fraction, the high level found in NEM-G. manilaensis might be associated with the high nutrient concentration present in water bodies during the rainy season [54-56,59]. A similar trend was reported for Palmaria palmata containing substantial levels of glutamic acid, serine, and alanine during winter and early spring, but absent in summer [58]. Specimens of G. fisheri and G. tenuistipitata collected in the rainy season had significantly higher levels of EAAs in contrast to a summer harvest [55]. Amongst the EAAs, histidine was quantified as the most limiting in NEM

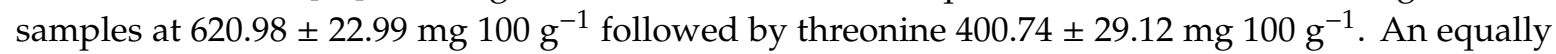
similar pattern was noticed by Sakthivel et al. [18] and Syad et al. [68], as obtained in G. edulis and Sargassum wightii with histidine levels at $3.3 \pm 0.16 \mathrm{mg} \mathrm{g}^{-1}$ and $7.44 \pm 0.44 \mathrm{mg} \mathrm{g}^{-1}$, respectively. Our data identified threonine and lysine as the highest EAAs in the SWM species with $231.73 \pm 8.66 \mathrm{mg} 100 \mathrm{~g}^{-1}$

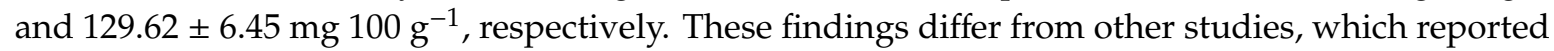
arginine and leucine as the most limiting AAs in G. changii and Bifurcaria bifurcata at $18.69 \%$ and $7.42 \%$, respectively $[19,45]$.

The EAAs/total amino acid ratio (0.05-0.17) was lower than those previously reported for Gracilaria spp. [23,68]. As for NEAAs, glutamic and aspartic acids were the most abundant, accounting between

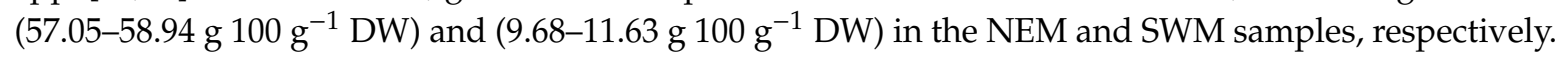
The high proportion of acidic AA (aspartic and glutamic acids) compared to basic AA is a characteristic of red seaweed [21,69]. Total acidic AA in the present study was higher than the data found in G. salicornia and G. changii $[19,56]$. The distinctive flavor and characteristic 'umami' taste of seaweeds are linked to aspartic and glutamic acids [70]. In terms of protein quality, NEM- G. manilaensis is greater

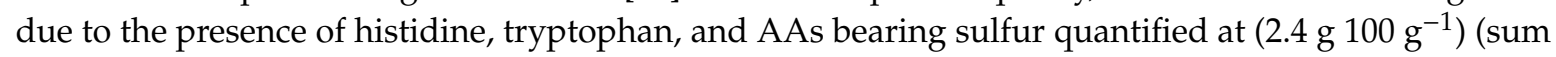
of Met and Cys) found lacking in the SWM samples. Histidine is known to contribute to antioxidant and anti-inflammatory properties [71]. The concentration of lysine, methionine, cysteine, tryptophan, and threonine is low in plants. In seaweed, cysteine is often reported to be deficient, but, when present, they are found in low concentrations $[18,72]$. Estimating their chemical score is essential in other to determine protein quality [73].

The protein quality and order of the restrictive AAs of G. manilaensis was measured by the chemical score for each EAAs using reference protein as proposed by Food and Agriculture Organization of the 
United Nations (FAO)/World Health Organization (WHO)/United Nations (UNU) for humans (children from 1-3-year-old, and adults) [74]. The AAs chemical score found in G. manilaensis during NEM and

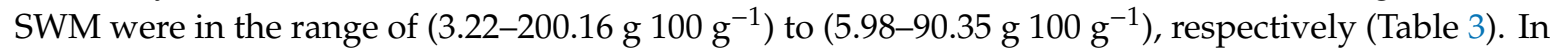
the NEM samples, tryptophan and lysine were the limiting AAs, whereas leucine and phenylalanine contributed to the lowest AAs score in SWM-G. manilaensis. A similar data was reported in edible red

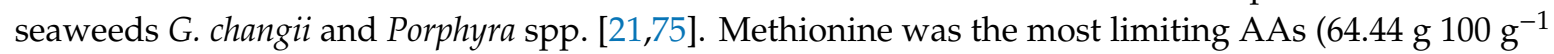
DW) found in G. changii [19]. As for the total EAAs requirement, G. manilaensis recorded a protein value of $41.49 \mathrm{mg} \mathrm{g}^{-1}$ and $146.59 \mathrm{mg} \mathrm{g}^{-1}$ during SWM and NEM monsoon, respectively. Therefore, consumption of $G$. manilaensis will offer a measurable quantity of the required essential amino acids.

The cell wall polysaccharides of macroalgae contain multiple functional groups, i.e., anionic carboxyl, amino, sulfhydryl, sulfate, and phosphate responsible for the high complexation of metallic cation from its surroundings [76]. They accumulate most of these metals without suffering any cell damage [77]. The macro, trace, and toxic elements differ widely in seaweed [78]. In this study, Ca content is higher than the level reported by Neto et al. [51] for different seaweeds: Ulva rigida $414.3 \pm 33.8 \mathrm{~g} 100^{-1} \mathrm{~g}$, Gracilaria spp. $200.4 \pm 24.3 \mathrm{~g} 100^{-1} \mathrm{~g}$, Fucus vesiculosus $1382.0 \pm 5.1 \mathrm{~g} 100^{-1} \mathrm{~g}$, and Saccharina latissimi $919.4 \pm 32.5 \mathrm{~g} 100^{-1} \mathrm{~g}$. However, lower Ca contents were reported for G. edulis

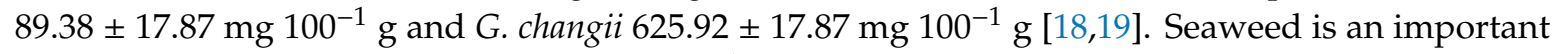

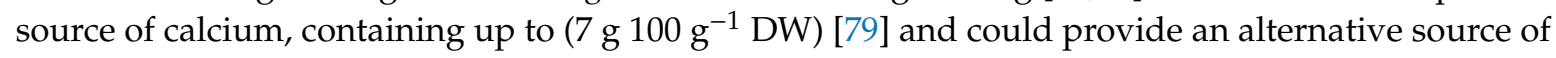
calcium for young, pre-, post-menopausal women and expectant mothers prone to calcium deficiency disorders such as osteoporosis and preeclampsia [80].

Seaweeds are known to be rich sources of $\mathrm{Na}$ and $\mathrm{K}$, however, with a low $\mathrm{Na} / \mathrm{K}$ ratio [35]. These

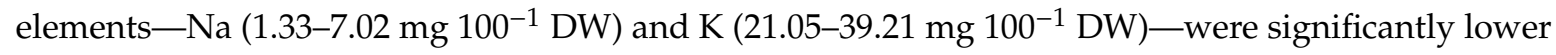
in both samples in comparison to the higher values found in Gracilaria spp $[18,51]$. The $\mathrm{Na}^{+} / \mathrm{K}^{+}$ratio of G. manilaensis $(0.03$ and 0.33 ) conforms with WHO dietary recommendations. Some studies have also reported low $\mathrm{Na} / \mathrm{K}$ ratios in Gracilaria spp $[18,68]$ suggesting that they can help neutralize modern dietary habits that are characterized by a high intake of $\mathrm{Na} / \mathrm{K}$ ratio diets $[19,67]$. The consumption of a high $\mathrm{Na} / \mathrm{K}$ ratio diet is linked to cardiovascular diseases and early death [78].

A significant amount of trace metal was recorded in G. manilaensis regardless of seasonal variation, and these might be attributed to the influence of growth dynamics [81]. Studies have shown that seaweed with low biomass corresponds to a high concentration of mineral elements and vice verse [82].

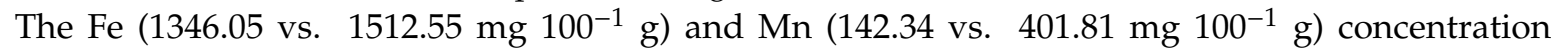
was high between the two harvest seasons. Similarly, Fe content, $1072.48 \pm 20.97 \mathrm{mg}^{100^{-1}} \mathrm{~g}$ and

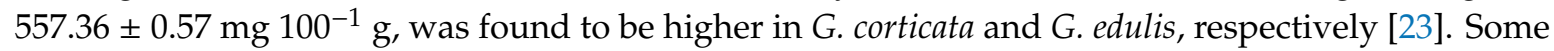
authors reported a much lower Fe content of $436.13 \mathrm{mg} 100^{-1} \mathrm{~g}$ DW and $0.46 \mathrm{mg}^{-1} \mathrm{~g}$ DW in G. changii and G. edulis, respectively $[18,19]$. In general, the iron content in G. manilaensis is higher than most terrestrial crops (2-4 mg $100^{-1} \mathrm{~g}$ ), such as legumes, cereal grains, nuts, and green leafy vegetables [83].

The estimated daily intakes (EDIs) of each trace metal was calculated assuming daily consumption of $8 \mathrm{~g}$ of dried seaweed based on a daily intake for an average adult $(70 \mathrm{~kg})$ in Asian cuisines [36]. In this regard, consumption of $8 \mathrm{~g}$ portion of G. manilaensis provides between (598 g $100 \mathrm{~g}^{-1}$ and

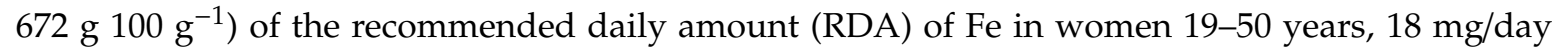
FNB / IOM (2001). Seaweed is also used as a dietary source of iron to prevent anemia caused by iron deficiency [84]. Manganese is beneficial for its metalloenzymes activities [72], and $8 \mathrm{~g}$ of G. manilaensis exceeded $100 \%$ of RDA required for adult male and female.

Studies have shown that red seaweed can accumulate heavy metals [81,85]. Based on PTWI health risk standards, daily consumption of SWM and NEM G. manilaensis samples (12.5 g/adult/day)

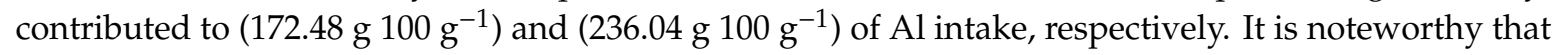
the $\mathrm{Al}$ concentration found in Gracilaria spp. during the two harvest seasons is well above the specified provisional tolerable weekly intake (PTWI) of 1 ppm of body weight (BW) $[86,87]$. These values were higher than those recorded by Larrea-Marín et al. [88] for Porphyra spp. $\left(15.0 \pm 2.55-220.8 \pm 7.95 \mu \mathrm{g} \mathrm{g}^{-1}\right.$ 
DW) and Laminaria spp. $\left(32.3 \pm 0.91-580.0 \pm 22.10 \mu \mathrm{g} \mathrm{g}^{-1} \mathrm{DW}\right)$ from Europe and Asia. The high Al content in G. manilaensis may be due to acidification of the surrounding soils in the area of harvest $[89,90]$.

The growing number of industries in Shoal, Johor, might be responsible for these elements entering the surrounding aquatic bodies [91-93]. Al toxicity may lead to pathophysiology of several neurodegenerative syndromes, i.e., Alzheimer, Parkinsonism, and dementia [94]. The level of Cd in NEM and SWM samples contributed less than $2 \%$ of PTWI, suggesting no health risk to potential consumers. The concentration of $\mathrm{Pb}$ and total As in both samples contributed between $\left(25-70{\left.\mathrm{~g} 100 \mathrm{~g}^{-1}\right)}^{-1}\right.$ of PTWI. In particular, large dietary consumption of $\mathrm{Pb}$ content might lead to health complications in the nervous system and other vital organs, such as kidney cancer and blood disorders [95]. The assessment of As toxicity depends on its chemical form; they exist in different forms, such as arsenic (III), arsenic (V) or other derivatives; arsenocholine, arsenobetaine, and arsenosugars [96]. Interestingly,

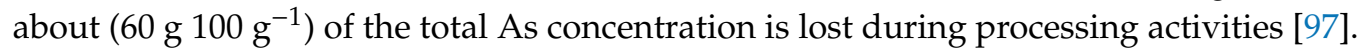

Vitamin analysis revealed vitamin B in a measurable concentration, while the other vitamin components were below the detection level. In contrast, other authors reported measurable quantities of different vitamins component in genus Gracilaria spp. [18,68]. The chlorophyll contents detected in G. manilaensis is low and in agreement with studies conducted by other authors $[18,68]$, who found that chlorophyll a and b of Gracilaria spp. range from $\left(3.06 \pm 0.28 \mu \mathrm{g} \mathrm{g}^{-1}\right.$ vs. $\left.1.583 \pm 0.049 \mu \mathrm{g} \mathrm{g}^{-1} \mathrm{DW}\right)$ and $\left(2.8 \pm 0.08 \mu \mathrm{g} \mathrm{g}^{-1}\right.$ vs. $\left.1.896 \pm 0.10 \mu \mathrm{g} \mathrm{g}^{-1} \mathrm{DW}\right)$, respectively. Similarly, G. edulis and G. corticata also presented chlorophyll a and b in the range of $(17.14 \mu \mathrm{g} / \mathrm{g} \mathrm{vs.} 8.96 \mu \mathrm{g} / \mathrm{g})$ and $(8.44 \mu \mathrm{g} / \mathrm{g}$ vs. $7.74 \mu \mathrm{g} / \mathrm{g})$, respectively [23].

Numerous studies have demonstrated the effect of temperature variations on the physicochemical properties of edible seaweed $[19,23,50,55]$. The SWC of G. manilaensis was in the range of some edible seaweeds, i.e., Sargassum wightii $\left(10 \pm 0 \mathrm{~mL} \mathrm{~g}^{-1} \mathrm{DW}\right)$, G. changii $\left(9.01 \pm 0.06-10.91 \pm 0.06 \mathrm{~mL} \mathrm{~g}^{-1} \mathrm{DW}\right)$ and G. edulis (20.0 mL/g DW) [18]. Likewise, WHC indicates a significant interaction between seaweed samples and temperature. These properties could be related to the hydrophilic nature of the charged polysaccharides (agar and carrageenan) and higher neutral sugar content found in the soluble dietary fibers of red seaweed [25]. A positive correlation between water retention has previously been observed in edible seaweed $[23,98]$. Similarly, our results were comparable to $\left(9.81 \pm 0.55 \mathrm{~g} \mathrm{~g}^{-1}-9.97 \pm 0.12 \mathrm{~g} \mathrm{~g}^{-1}\right.$ DW) found for G. edulis and $\left(9.93 \pm 0.08 \mathrm{~g} \mathrm{~g}^{-1} \mathrm{DW}-11.59 \pm 0.04 \mathrm{~g} \mathrm{~g}^{-1} \mathrm{DW}\right)$ reported for G. changii $[18,19]$. However, values of WHC are difficult to compare, because they depend on experimental conditions (temperature, time, and centrifugation) and sample preparation $[99,100]$. The higher values of WHC in G. manilaensis indicate they might be used as a functional ingredient for producing low-calorie food such as snacks, corn flakes, crackers, and cookies [100]. Oil holding capacity (OHC) is also a functional property, and food ingredients with high OHC values allow for the stabilization of food emulsions and high-fat food products. In this study, there were variations in $\mathrm{OHC}$ between the seaweed samples, which might be due to the physical entrapment of oil by capillary attraction [101]. The OHC in G. manilaensis was comparable to other Gracilaria spp. $[18,19,55]$. The hydrophobicity of proteins also plays a significant role in fat absorption $[55,98]$. Overall, the results of physicochemical properties confirmed that G. manilaensis could be consumed as a source of food ingredients, dietary fibers, and proteins.

Studies have reported the antibacterial properties of seaweed extracts [102-104]. In this study, extracts dilutions from G. manilaensis did not inhibit the growth of the bacteria screened. Arulkumar, et al. [105] related antimicrobial activity from G. corticata and G. edulis to the presence of unsaturated fatty acids, organic acids, and phenol compounds. However, the fatty acid profile of G. manilaensis lacked PUFAs and did not show a zone of inhibition against the tested pathogenic organism. These results are not in conformity with Deepak et al. [106] and Narasimhan et al. [107], who reported seasonal variation in the antibacterial activities of Gracilaria against different Gram-positive and Gram-negative bacteria. Variability in the production of metabolites in seaweed, which is linked to seasonal variation, could have affected the antibacterial properties of the studied seaweed [108]. Seaweed collected in the summer has been reported to exhibit higher physiological activities due 
to active metabolites, including fatty acids, phlorotannins, pigments, lectins, alkaloids, terpenoids, and halogenated compounds found in them as a form of adaptation [109]. In this experiment, the samples were collected in August and November, where water temperature was colder at $28^{\circ} \mathrm{C}$, which might attribute to the absence of activity. However, there is no data on seasonal variation of seaweed bioactivity in Malaysia for comparison. As such, further study is required to confirm these findings.

\section{Materials and Methods}

\subsection{Biomass sampling and Preparation}

The Malaysian climate is modulated primarily by the Southeast Asian monsoon with a cycle of two opposite regimes, i.e., winter monsoon [locally known as the northeast monsoon (NEM)] and the summer monsoon [locally known as the southwest monsoon (SWM)]. The SWM begins in late May and ends in late September, while the NEM commences around November and retreats in March of the subsequent year [29]. The country receives substantial rainfall all year-round, but the amount peaks during the NEM period [110]. The SWM season between brings less rainfall, with a recorded total monthly rainfall as low as $4.8 \mathrm{~mm}$. According to available reports, the average annual total rainfall and evaporation were $1862 \mathrm{~mm}$ and $1098 \mathrm{~mm}$, respectively [111]. However, the rate of evaporation is affected by temperature and cloudiness, and when it is cloudy, there is less sunshine, resulting in less solar radiation and lower temperature. The drier months have higher evaporation, while the rainy months have lower, influencing water body salinity [112-114]. The salinity of Malaysian waters ranges between 28 and $34[115,116]$, while surface water temperature also fluctuates between $25.0^{\circ} \mathrm{C}$ and $30.5^{\circ} \mathrm{C}[117]$.

Specimens of G. manilaensis (Rhodophyta, Rhodophyceae) were collected twice by hand in August 2018 and November 2018 during the SWM and NEM, respectively, from Merambong shoal $\left(1^{\circ} 20^{\prime} 14.53^{\prime \prime}\right.$ $\mathrm{N}, 103^{\circ} 36^{\prime} 08.70^{\prime \prime}$ E) in the southern tip of Peninsular Malaysia in the Straits of Johor. These are periods of optimal harvesting, as they signal the end of the growth season of some seaweeds in Malaysia $[118,119]$. Besides, the growth of seaweeds reacts to a broad variety of ever-changing biotic and physical abiotic factors [120]. Approximately 3 to $5 \mathrm{~kg}$ of tissue was collected in each harvest. To prevent physiological injury during harvesting, the algae stem was not separated. Within $24 \mathrm{~h}$ of collection, they were transported to the laboratory in an ice-cold box containing seawater to prevent evaporation, thoroughly washed and cleaned with distilled water to remove contaminants (epiphytes, sand, and debris), and dried at room temperature [104]. Voucher specimens were identified by Prof Siew-Moi Phang and deposited at the Institutes of Earth and Ocean Sciences, University of Malaya. The dried sample was milled to powder using a Waring blender and stored airtight under $-20{ }^{\circ} \mathrm{C}$ for further analysis.

\subsection{Estimation of Moisture and Ash}

Moisture content was determined gravimetrically by measuring sample $(3 \mathrm{~g})$ weight loss by drying in a hot air oven (Memmert UFP 600, Schwabach, Germany) at $105^{\circ} \mathrm{C}$ until a constant weight was obtained (AOAC 934.01) [121]. Moisture content is expressed either as a percent of the oven-dry mass or of the as-received mass (A5TM D 2974-87). Ash content was quantified gravimetrically after incineration of dried algal material at $550{ }^{\circ} \mathrm{C}$ for $18 \mathrm{~h}$ using an electric muffle furnace (Barnstead Thermolyne) (AOAC 930.05) [122]. The leftover residue after incineration is ash. The ash content is expressed as a percentage of the mass of the oven-dried sample.

\subsection{Estimation of Total Crude Protein}

Crude protein percentage was quantified according to the classical micro-Kjeldahl method $(\mathrm{N} \times 6.25)$ [121] using a Foss Kjeltec system as described by Zhou et al. [123]. Five-hundred mg of freeze-dried algae samples wrapped in nitrogen-free paper were oxidized in a long neck $250-\mathrm{mL}$ digestion flask containing concentrated sulphuric acid $(15 \mathrm{~mL})$, and a mixture of potassium sulfate $(7 \mathrm{~g})$ 
and cupric sulfate $(0.5 \mathrm{~g})$. They were digested using a Gerhardt Kjeldatherm digester at $420{ }^{\circ} \mathrm{C}$ until a clear and colorless liquid was obtained, which indicates the complete breakdown of all organic matter. Neutralization, distillation, and titration were done simultaneously in a Foss Kjeltec 8400 Analyser unit, as the results were obtained in percent of dry weight. The content of non-protein nitrogen (NPN) fraction in G. manilaensis was obtained after precipitation of the proteins with trichloracetic acid $(10 \%)$ [34]. Pure protein content resulted from the difference between crude protein and NPN contents.

\subsection{Amino Acid Profile}

The amino acid (AA) content of G. manilaensis was determined based on AOAC 999.13 with automatic online OPA/FMOC derivatization by RP-HPLC using a Shimadzu LC system (Shimadzu Corporation, Kyoto, Japan) equipped with an LC-20AD pump, DGU-20AS degasser and photodiode array SPD-M20A (PAD), and fluorescence RF-10AXL (FLD) detectors on line [20]. About $2 \mathrm{~g}$ of powdered G. manilaensis samples (total and free amino acid extracts) were derivatized with o-phthalaldehyde (OPA) and 9-fluorenylmethyl chloroformate (FMOC) (Sigma-Aldrich (Steinheim, Germany), agreeing to a protocol by Heems et al. [124]. The derivatized amino acid solutions were filtered through a $0.22 \mu \mathrm{m}$ microfiltration membrane, and the filtrates $(20.0 \mu \mathrm{L})$ were injected onto the RP-HPLC system equipped with an HPLC column (Zorbax Eclipse XDB-C18 $(4.6 \times 250 \mathrm{~mm})$ conditioned at $27 \pm 0.1^{\circ} \mathrm{C}$. The OPA-3-MPA derivatives were detected by a programmable fluorimeter with excitation ( $\lambda$ ex) and emission ( $\lambda \mathrm{em}$ ) wavelengths set at 338 and $262 \mathrm{~nm}$, respectively, while the FMOC derivatives were identified at $\lambda$ ex 260nm and $\lambda$ em $315 \mathrm{~nm}$; wavelength change occurred at $18.5 \mathrm{~min}$. The mobile phase used was a combination of $10 \mathrm{mM}$ disodium hydrogen phosphate buffer: $10 \mathrm{mM}$ disodium tetraborate and $5 \mathrm{mM}$ sodium azide adjusted to $\mathrm{pH} 8.2$ eluent (A), and a mixture of acetonitrile, methanol, and water with a ratio of $45: 45: 10(v / v / v)$ as eluent $B$, at a flow rate of $1.0 \mathrm{~mL} \mathrm{~min}^{-1}$. The amino acid standards mix (AAS18, Sigma Aldrich, MO, USA) was dissolved in 0.1 M hydrochloric acid and diluted appropriately to obtain a working solution with norvalin (Merck, MO, USA) used as the internal standard.

\section{Chemical Score}

The amino acid (AA) contents was then compared with the FAO reference pattern as described by FAO [74]. The AA score of essential amino acids (EAAs) was calculated using the following equation:

AA score $(\%)=(\mathrm{mg}$ EAA in $1 \mathrm{~g}$ of test protein $) /(\mathrm{mg}$ EAA in $1 \mathrm{~g}$ of reference protein $) \times 100$

\subsection{Estimation of Crude Lipids}

The total weight of the lipid extract was determined using the modified Folch Extraction method, as described by Gosch et al. [125]. Two-hundred milligram of the freeze-dried algae sample, weighed into a Teflon capped glass vial, was homogenized in $5 \mathrm{~mL}$ chloroform: methanol $(2: 1, v / v)$ mixture at $60{ }^{\circ} \mathrm{C}$ for $1 \mathrm{~h}$. The mixture was filtered using a vacuum pump, while an additional $4 \mathrm{~mL}$ of the chloroform-methanol mixture was used to rinse both the filter paper and the vacuum flask to recover all lipids. The filtered crude extract was washed with $1.8 \mathrm{~mL}$ of $0.9 \% \mathrm{NaCl}$ into a pre-weighed vial and centrifuged to enable phase separation with lower organic phase (chloroform); it contained the lipids collected and evaporated to dryness using a Speed Vac Concentrator. The total lipid content was determined gravimetrically.

Fatty Acid Composition

The fatty acid (FA) composition of G. manilaensis was quantified using Gas Chromatography (Hydrogen Flame Ionization Detector) GC FID, according to standard method AOAC 996.06, as described by Petrović et al. [126]. Inputs for the instrument were temperature injector-225 ${ }^{\circ} \mathrm{C}$; carrier gas—helium; flow rate-0.75mL/min using a capillary column (Rt-2560, $100 \mathrm{~m}, 0.25 \mathrm{~mm}$ ID, $0.2 \mathrm{um} \mathrm{df}$ ). Aliquots of the extracted lipids samples were saponified and methylated to fatty acid methyl esters 
(FAME Mix C4-C24 (18919 Supelco) using Boron trifluoride (BF3) in 0.5N methanolic solution against C11.0 triglycerides internal standard (Tokyo, Japan).

\subsection{Estimation of Total Carbohydrate}

Total carbohydrate content $(\%)$ was estimated by weight difference $(100-$ [moisture + ash + crude protein + crude lipid]) [127].

\subsection{Estimation of Gross Calorific Value}

The gross calorific value was estimated using the Isoperibol oxygen bomb calorimeter (IKA Calorimeter System C 2000 basic) standardized with benzoic acids. Two-hundred mg of dried algae samples were made into pellets, combusted in oxygen at 200 bar (2900 PSI) and a core temperature of up to $1000^{\circ} \mathrm{C}\left(1800^{\circ} \mathrm{F}\right)$. The total calories were calculated on an ash-free basis $[128,129]$.

\subsection{Estimation of Total Dietary Fiber}

The total dietary fiber content in seaweeds was determined according to the (AOAC, 1995) enzymatic-gravimetric method AOAC 985.29 [99].

\subsection{Estimation of Chlorophyll $A$ and $B$}

Spectrophotometric determination of Chlorophyll (A and B) was estimated according to a method by Rosemary et al. [23] with slight modification. One gram of freeze-dried seaweed was dissolved and homogenized in 96\% methanol (Glas-col High-speed homogenizer) at $1000 \mathrm{rpm}$ for one minute. The seaweed extract was centrifuged at $1000 \mathrm{rpm}$ for $1 \mathrm{~min}$. The filtered supernatant was centrifuged (Eppendorf Centrifuge 5810R) at $2500 \mathrm{rpm}$ for $10 \mathrm{~min}$ and the absorbance measured at a range of 400-700 nm on a Shimadzu UV-Vis 1800 spectrophotometer. Chlorophyll A and B content was expressed as ( $\mu \mathrm{g} / \mathrm{g}$ of dry weight), calculated according to the following equations:

$$
\begin{aligned}
& \text { Chlorophyll A = } 15.65(\mathrm{~A} 666)-7.340(\mathrm{~A} 653) \\
& \text { Chlorophyll B }=27.05(\mathrm{~A} 653)-11.21(\mathrm{~A} 666)
\end{aligned}
$$

\subsection{Estimation of Vitamin Content}

Vitamin content of G. manilaensis was evaluated using HPLC (LC, Agilent, USA) method BS EN 14130:2003 and nutrition labelling analysis 1993 No. 992.06 with slight modification [130], based on the following conditions: column (Zorbax Eclipse $-\mathrm{C} 18(4.6 \times 250 \mathrm{~mm}$ ) and injection volume $20 \mu \mathrm{L}$. Mobile phase methanol: water (95:5) and $0.05 \mathrm{M}$ ammonium acetate for Vit B1 and B2 set at UV $270 \mathrm{~nm}-1.0 \mathrm{~mL} / \mathrm{min}$. Hexane and Isopropanol: $100+0.25 \mathrm{~mL}$ for Vit A and E set at UV $336 \mathrm{~nm}$ (flow rate $0.5 \mathrm{~mL} / \mathrm{min}$ for $\mathrm{B} 1$ and B2) and UV $264 \mathrm{~nm}$ for $\mathrm{D}$ (flow rate $1.0 \mathrm{~mL} / \mathrm{min}$ ). For Vitamin C, the method used was BS EN 14130:2003 Mobile Phase 0.85\% Orthophosphoric Acid with UV detector $265 \mathrm{~nm}$ and flow rate $0.7 \mathrm{~mL} / \mathrm{min}$. Standards include Retinyl acetate and Retinyl Palmitate $(7.5 \mu \mathrm{g} / \mathrm{mL})$, $\alpha$-tocopherol $(2 \mathrm{mg} / \mathrm{mL}$ ), and (Vitamin A, E, C, D at $1 \mathrm{mg} / \mathrm{mL}$ ).

\subsection{Mineral and Heavy Metal Analysis}

The mineral and heavy metal content was quantified using ICP-MS (Agilent 7700) with slight modification. About $0.5 \mathrm{~g}$ freeze-dried Gracilaria spp. was subjected to wet hydrolysis using a high-pressure polytetrafluoroethylene (PTFE) vessel containing $6 \mathrm{~mL}$ of $65 \% \mathrm{HNO}_{3}$ and $2 \mathrm{~mL}$ of $35 \%$ $\mathrm{H}_{2} \mathrm{O}_{2}$, and digested in an Anton Paar microwave. After digestion, the samples were filtered and diluted with Milli-Q water to a final volume of $50 \mathrm{~mL}$ and analyzed in an Agilent 7700 series ICP-MS for multi-mineral elements, as adopted by NMKL (Nordic Committee on Food Analysis) method 22, as well as a CEN (European Normalization Organization) method EN 15763:2009.23. The total 
concentrations of freeze-dried seaweed minerals were then quantified from the calibration curves of their respective standard elements [131].

\subsection{Physicochemical Properties of Seaweeds}

Swelling capacity (SWC) and water holding capacity (WHC) were determined as per the method described by Sakthivel and Devi [18], while oil holding capacity (OHC) was measured according to Yaich et al. [98].

\subsubsection{Swelling Capacity (SWC)}

SWC was measured by the bed volume technique, as per Sakthivel and Devi [18]. About $200 \mathrm{mg}$ of Gracilaria spp. was dissolved in $20 \mathrm{~mL}$ of distilled water; the mixture was stirred vigorously and conditioned separately at two different temperatures-25 ${ }^{\circ} \mathrm{C}$ and $37^{\circ} \mathrm{C}$-separately to measure its effect on SWC. The swelling volume was measured and expressed as $\mathrm{ml}$ of swollen sample per $\mathrm{g}$ of sample dry weight (DW):

$$
\text { SWC }=\text { Initial volume of water }(\mathrm{mL})-\text { volume of water after incubation }(\mathrm{mL})
$$

\subsubsection{Water Holding Capacity (WHC)}

Water absorption of Gracilaria spp. was measured by the centrifugation method, according to Sakthivel and Devi [18]. About $200 \mathrm{mg}$ of seaweed sample was dissolved in $20 \mathrm{~mL}$ of distilled water and kept in an incubator shaker at RPM 250 (IKA KS 4000I) for $24 \mathrm{~h}$ before it was conditioned separately at two different temperatures $-25^{\circ} \mathrm{C}$ and $37^{\circ} \mathrm{C}$. The supernatant was discarded after centrifugation for $25 \mathrm{~min}$ at $3000 \mathrm{~g}$ and the moisture content estimated by dehydration in an oven at $160^{\circ} \mathrm{C}$ for two $\mathrm{h}$. WHC is expressed as the grams of water held by $1 \mathrm{~g}$ of dry weight of the sample.

$$
\text { WHC }=\text { Wet weight of the sample }(\mathrm{g}) \text { - Dry weight of the sample }(\mathrm{g})
$$

\subsubsection{Oil Holding Capacity (OHC)}

The oil holding capacity of Gracilaria spp. was measured according to a method described by Yaich et al. [98]. About $0.5 \mathrm{~g}$ of seaweed sample was dissolved in $6.0 \mathrm{~mL}$ of corn oil in a centrifugation tube. The tubes were agitated for $30 \mathrm{~min}$ in an incubator shaker (RPM 250) (IKA KS 4000I) at $25^{\circ} \mathrm{C}$ and $37^{\circ} \mathrm{C}$. Then the oil supernatant was measured at $2500 \mathrm{~g}$ for $30 \mathrm{~min}$ (Eppendorf Centrifuge 5810R) at room temperature. The $\mathrm{OHC}$ of seaweed was measured as the number of grams of oil held by $1 \mathrm{~g}$ of dry weight of the sample:

$$
\mathrm{OHC}=\text { Initial volume of oil }(\mathrm{g})-\text { Volume of oil after incubation }(\mathrm{g})
$$

\subsubsection{Antimicrobial Properties}

About 1350-1500 g of freshly harvested red seaweed G. manilaensis was soaked separately in $7500 \mathrm{~mL}$ of methanol $(100 \%)$ at a ratio of $1: 5$ (powder/solvent) for seven days. The mixture was agitated multiple times during the soaking period to ensure maximum homogeneity and extraction of macroalgae constituents. The mixtures were first filtered by cheese cloth and then by Whatman No. 1 filter paper. The filtrate was then concentrated under reduced pressure by using a rotary evaporator at $40{ }^{\circ} \mathrm{C}$ to complete dryness, yielding $12-15 \mathrm{~g}(0.8-1.0 \%)$ of crude methanolic extract [132]. The crude methanolic extract was subjected to partitioning in a separating funnel with a mixture of two solvents-water and ethyl acetate (EtOAc) - at a ratio of 3:1, and then concentrated in vacuo to produce both water and EtOAc concentrate. The G. manilaensis from NEM produced $1.97 \mathrm{~g}$, a higher yield than G. manilaensis obtained from SWM $(1.02 \mathrm{~g})$.

The solid crude extracts (31.5-500 $\mu \mathrm{g})$, obtained from the lyophilised G. manilaensis were dissolved and diluted with EtOAc solvent. Sterilised 6-mm filter paper discs loaded with $20 \mu \mathrm{L}$ of the seaweed 
extract were transferred to sterile petri dishes. The discs were allowed to remain at room temperature until complete diluent evaporation and kept under refrigeration until use. The antibacterial activity was evaluated by standard disc diffusion assay against four pathogenic Gram-negative bacterial strains-Pseudomonas aeruginosa, Klebsiella pneumoniae, Escherichia coli, and Salmonella serovar typhi-as well as two Gram-positive bacterial strains-Staphylococcus aureus and Bacillus subtilis—on Mueller Hilton agar (Difco, US), as described by Bauer et al. [37]. Pure bacterial strains were obtained from the Department of Microbiology, School of Health Sciences, Universiti Sains Malaysia, and were subsequently grown at $37^{\circ} \mathrm{C}$ and maintained on nutrient agar (Merck, Germany). Bacterial isolates were grown overnight in Mueller Hilton broth (Merck, Germany) at $30^{\circ} \mathrm{C}$. Before inoculation, bacterial cell density was adjusted to turbidity equalling the standard McFarland $0.5 \mathrm{at} 600 \mathrm{~nm}$. Discs loaded with extracts were placed onto the Mueller Hilton agar (MHA) containing $100 \mu \mathrm{L}$ standardized bacterial suspension and incubated at $30^{\circ} \mathrm{C}$ for $24 \mathrm{~h}$ under aerobic conditions. Prior to incubation, all Petri dishes were placed in the refrigerator for $40 \mathrm{~min}$ to retard microbial growth. Imipenem was used as a positive control, and analytical EtOAc was used as negative control. The inhibition zone was expressed as the diameter of the inhibition zone around the discs in $\mathrm{mm}$ after overnight incubation. Tests were performed in duplicate.

\subsection{Statistical Analysis}

All of the analyses were performed in triplicates $(n \geq 3)$ and the results are presented as means \pm S.D. except Dietary Fiber $(n \geq 2)$. Paired sample $t$-test was used to compare composition values and significant difference between the mean values of NEM and SWM specimen harvested in the two seasons. One-way analysis of variance (ANOVA) and Duncan's test was used to compare the effects of temperature on the physicochemical properties. All determinations were performed using SPSS 24.0 (Statistical Package for the Social Sciences, SPSS Inc., Chicago, IL, USA). A significant positive variation was defined at the significance level of $p<0.05$.

\section{Conclusions}

This study discovered pronounced seasonal variation in the biochemical composition of G. manilaensis for future exploitation as sustainable sources of food ingredients. Currently, there is no published data on harvest time and its relation to the biochemical and nutritional composition of the edible G. manilaensis species in Malaysia. Regarding the biochemical composition of G. manilaensis, NEM samples presented the maximum values for almost all the components investigated when compared to the SWM samples, with a significant difference. The EAAs and NEAAs were significantly higher in NEM samples, as well as proximate and gross energy value. However, high ash content was observed in the SWM, which was also reflected in the total mineral content. The lipids components showed no statistically significant difference; however, the SWM samples contained higher amounts of monounsaturated oleic acid. With respect to physicochemical properties, both samples from NWM and SWM could be considered as sources of food ingredients, including proteins, and dietary and soluble fiber. In view of these results, this study suggests that NWM and SWM samples contains important nutritive components that may significantly contribute to both human and animal nutritional requirements. Furthermore, they could serve as potential sources of mineral supplements, although the presence of high levels of aluminum and lead, which is perhaps attributed largely to the presence of human activities in coastal areas, may discourage its utilization as food and feed purposes. However, the beneficial or detrimental health effects of specific nutrients available in food depend on their absorption in the gut (which is also a function of the body's processing conditions) and interaction with other components.

Author Contributions: Conceptualization, S.A.R. and K.P.; methodology, A.Q.A.; software, S.A.R.; validation, F.G., K.P.; formal analysis, A.Q.A.; investigation, A.Q.A.; resources, S.A.R.; data curation, A.Q.A.; writing-original draft preparation, A.Q.A.; writing —review and editing, S.A.R. and K.P.; supervision, S.A.R.; project administration, M.R.-I.; funding acquisition, M.R.-I. and S.A.R. 
Funding: This research is funding by RP018A-16SUS University Malaya Research Grant (UMRG), Institution Centre of Excellence (HiCOE) Phase II Fund, Ministry of Higher Education (IOES-2014D) and the Universiti Sains Malaysia, School of Health Sciences Research Incentive Grant.

Acknowledgments: The authors thanks Affendi Yang Amri, Jillian Ooi, Kelab Alami Mukim Tg Kupang and Serina Rahman for help with the collection of samples off the Merambong Shoales Johore Straits, Western Peninsular Malaysia.

Conflicts of Interest: The authors declare that there are no conflict of interest.

\section{References}

1. Fan, S.; Brzeska, J. Sustainable food security and nutrition: Demystifying conventional beliefs. Glob. Food Secur. 2016, 11, 11-16. [CrossRef]

2. FAO, U. How to feed the world in 2050. In Proceedings of the Rome High-Level Expert Forum, Rome, Italy, November 2017.

3. Godfray, H.C.J.; Beddington, J.R.; Crute, I.R.; Haddad, L.; Lawrence, D.; Muir, J.F.; Pretty, J.; Robinson, S.; Thomas, S.M.; Toulmin, C. Food Security: The Challenge of Feeding 9 Billion People. Science 2010, 327, 812-818. [CrossRef] [PubMed]

4. Wan, A.H.L.; Davies, S.J.; Soler-Vila, A.; Fitzgerald, R.; Johnson, M.P. Macroalgae as a sustainable aquafeed ingredient. Rev. Aquac. 2019, 11, 458-492. [CrossRef]

5. Kadam, S.U.; Tiwari, B.K.; O'Donnell, C.P. Application of Novel Extraction Technologies for Bioactives from Marine Algae. J. Agric. Food Chem. 2013, 61, 4667-4675. [CrossRef] [PubMed]

6. Barros, F.C.; da Silva, D.C.; Sombra, V.G.; Maciel, J.S.; Feitosa, J.P.; Freitas, A.L.; de Paula, R.C. Structural characterization of polysaccharide obtained from red seaweed Gracilaria caudata (J Agardh). Carbohydr. Polym. 2013, 92, 598-603. [CrossRef] [PubMed]

7. Guiry, M. AlgaeBase. World-wide electronic publication. Available online: http://www.algaebase.org (accessed on 09 March 2019).

8. McHugh, D.J. Worldwide distribution of commercial resources of seaweeds including Gelidium. In International Workshop on Gelidium; Springer: Dordrecht, the Netherlands, 1991; Volume 21, pp. 19-29.

9. Torres, P.; Santos, J.P.; Chow, F.; dos Santos, D.Y. A comprehensive review of traditional uses, bioactivity potential, and chemical diversity of the genus Gracilaria (Gracilariales, Rhodophyta). Algal Res. 2019, 37, 288-306. [CrossRef]

10. Guiry, M. AlgaeBase. World-Wide Electronic Publication, National University of Ireland, Galway. Available online: http://www.algaebase.org/ (accessed on 15 March 2019).

11. Fleurence, J. Seaweeds as food. In Seaweed in Health and Disease Prevention; Elsevier: Amsterdam, The Netherlands, 2016; pp. 149-167.

12. Yang, L.-E.; Lu, Q.-Q.; Brodie, J. A review of the bladed Bangiales (Rhodophyta) in China: History, culture and taxonomy. Eur. J. Phycol. 2017, 52, 251-263. [CrossRef]

13. Radulovich, R.; Umanzor, S.; Cabrera, R.; Mata, R. Tropical seaweeds for human food, their cultivation and its effect on biodiversity enrichment. Aquaculture 2015, 436, 40-46. [CrossRef]

14. Chapman, A.S.; Stévant, P.; Larssen, W.E. Food or fad? Challenges and opportunities for including seaweeds in a Nordic diet. Bot. Mar. 2015, 58, 423-433. [CrossRef]

15. Garcia-Vaquero, M.; Hayes, M. Red and green macroalgae for fish and animal feed and human functional food development. Food Rev. Int. 2016, 32, 15-45. [CrossRef]

16. Meinita, M.D.N.; Marhaeni, B.; Winanto, T.; Jeong, G.-T.; Khan, M.N.A.; Hong, Y.-K. Comparison of agarophytes (Gelidium, Gracilaria, and Gracilariopsis) as potential resources for bioethanol production. J. Appl. Phycol. 2013, 25, 1957-1961. [CrossRef]

17. Sade, A.; Ali, I.; Ariff, M.R.M. The seaweed industry in Sabah, east Malaysia. Jati-J. Southeast. Asian Stud. 2006, 11, 97-107.

18. Sakthivel, R.; Devi, K.P. Evaluation of physicochemical properties, proximate and nutritional composition of Gracilaria edulis collected from Palk Bay. Food Chem. 2015, 174, 68-74. [CrossRef] [PubMed]

19. Chan, P.T.; Matanjun, P. Chemical composition and physicochemical properties of tropical red seaweed, Gracilaria changii. Food Chem. 2017, 221, 302-310. [CrossRef] [PubMed] 
20. Vieira, E.F.; Soares, C.; Machado, S.; Correia, M.; Ramalhosa, M.J.; Oliva-teles, M.T.; Carvalho, A.P.; Domingues, V.F.; Antunes, F.; Oliveira, T.A.C. Seaweeds from the Portuguese coast as a source of proteinaceous material: Total and free amino acid composition profile. Food Chem. 2018, 269, 264-275. [CrossRef] [PubMed]

21. Norziah, M.H.; Ching, C.Y. Nutritional composition of edible seaweed Gracilaria changgi. Food Chem. 2000, 68, 69-76. [CrossRef]

22. Jiménez-Escrig, A.; Sánchez-Muniz, F. Dietary fibre from edible seaweeds: Chemical structure, physicochemical properties and effects on cholesterol metabolism. Nutr. Res. 2000, 20, 585-598. [CrossRef]

23. Rosemary, T.; Arulkumar, A.; Paramasivam, S.; Mondragon-Portocarrero, A.; Miranda, J.M. Biochemical, Micronutrient and Physicochemical Properties of the Dried Red Seaweeds Gracilaria edulis and Gracilaria corticata. Molecules 2019, 24, 2225. [CrossRef] [PubMed]

24. Roohinejad, S.; Koubaa, M.; Barba, F.J.; Saljoughian, S.; Amid, M.; Greiner, R. Application of seaweeds to develop new food products with enhanced shelf-life, quality and health-related beneficial properties. Food Res. Int. 2017, 99, 1066-1083. [CrossRef] [PubMed]

25. Gómez-Ordóñez, E.; Jiménez-Escrig, A.; Rupérez, P. Dietary fibre and physicochemical properties of several edible seaweeds from the northwestern Spanish coast. Food Res. Int. 2010, 43, 2289-2294. [CrossRef]

26. Bocanegra, A.; Bastida, S.; Benedi, J.; Rodenas, S.; Sanchez-Muniz, F.J. Characteristics and nutritional and cardiovascular-health properties of seaweeds. J. Med. Food 2009, 12, 236-258. [CrossRef] [PubMed]

27. Lahaye, M.; Kaeffer, B. Seaweed dietary fibres: Structure, physico-chemical and biological properties relevant to intestinal physiology. Sci. Des Aliment. (Fr.) 1997, 17, 563-584.

28. Phang, S. Seaweed resources in Malaysia: Current status and future prospects. Aquat. Ecosyst. Health Manag. 2006, 9, 185-202. [CrossRef]

29. Phang, S.-M.; Yeong, H.-Y.; Lim, P.-E. The seaweed resources of Malaysia. Botanica Mar. 2019, 62, 265. [CrossRef]

30. Abdullah, N.S.; Muhamad, S.; Omar, I.C.; Abdullah, H. Fatty acids profiles of red seaweed, Gracilaria manilaensis. Exp. 2013, 11, 726-732.

31. Andriani, Y.; Syamsumir, D.F.; Yee, T.C.; Harisson, F.S.; Herng, G.M.; Abdullah, S.A.; Orosco, C.A.; Ali, A.M.; Latip, J.; Kikuzaki, H. Biological activities of isolated compounds from three edible Malaysian red seaweeds, Gracilaria changii, G. manilaensis and Gracilaria Spp. Nat. Prod. Commun. 2016, 11, 1117-1120.

32. Pang, J.-R.; Goh, V.M.-J.; Tan, C.-Y.; Phang, S.-M.; Wong, K.-H.; Yow, Y.-Y. Neuritogenic and in vitro antioxidant activities of Malaysian Gracilaria manilaensis Yamamoto \& Trono. J. Appl. Phycol. 2018, 30, 3253-3260.

33. Mæhre, H.K.; Malde, M.K.; Eilertsen, K.E.; Elvevoll, E.O. Characterization of protein, lipid and mineral contents in common Norwegian seaweeds and evaluation of their potential as food and feed. J. Sci. Food Agric. 2014, 94, 3281-3290. [CrossRef]

34. Dawczynski, C.; Schubert, R.; Jahreis, G. Amino acids, fatty acids, and dietary fibre in edible seaweed products. Food Chem. 2007, 103, 891-899. [CrossRef]

35. MacArtain, P.; Gill, C.I.; Brooks, M.; Campbell, R.; Rowland, I.R. Nutritional value of edible seaweeds. Nutr. Rev. 2007, 65, 535-543. [CrossRef]

36. Mišurcová, L.; Machů, L.; Orsavová, J. Seaweed minerals as nutraceuticals. In Advances in Food and Nutrition Research; Elsevier: Amsterdam, The Netherlands, 2011; Volume 64, pp. 371-391.

37. Bauer, A.; Kirby, W.; Sherris, J.C.; Turck, M. Antibiotic susceptibility testing by a standardized single disk method. Am. J. Clin. Pathol. 1966, 45, 493-496. [CrossRef] [PubMed]

38. Rødde, R.S.H.; Vårum, K.M.; Larsen, B.A.; Myklestad, S.M. Seasonal and geographical variation in the chemical composition of the red alga Palmaria palmata (L.) Kuntze. Bot. Mar. 2004, 47, 125-133. [CrossRef]

39. Ito, K.; Hori, K. Seaweed: Chemical composition and potential food uses. Food Rev. Int. 1989, 5, 101-144. [CrossRef]

40. Naidoo, K.; Maneveldt, G.; Ruck, K.; Bolton, J.J. A comparison of various seaweed-based diets and formulated feed on growth rate of abalone in a land-based aquaculture system. J. Appl. Phycol. 2006, 18, 437-443. [CrossRef]

41. Cox, S.; Gupta, S.; Abu-Ghannam, N. Effect of different rehydration temperatures on the moisture, content of phenolic compounds, antioxidant capacity and textural properties of edible Irish brown seaweed. LWT 2012, 47, 300-307. [CrossRef] 
42. Patarra, R.F.; Paiva, L.; Neto, A.I.; Lima, E.; Baptista, J. Nutritional value of selected macroalgae. J. Appl. Phycol. 2011, 23, 205-208. [CrossRef]

43. Gupta, S.; Cox, S.; Abu-Ghannam, N. Effect of different drying temperatures on the moisture and phytochemical constituents of edible Irish brown seaweed. LWT-Food Sci. Technol. 2011, 44, 1266-1272. [CrossRef]

44. FAO. FAO Yearbook: Fishery and Aquaculture Statistics; Fao: Rome, Italy, 2016.

45. Lorenzo, J.M.; Agregán, R.; Munekata, P.E.; Franco, D.; Carballo, J.; Şahin, S.; Lacomba, R.; Barba, F.J. Proximate composition and nutritional value of three Macroalgae: Ascophyllum nodosum, Fucus vesiculosus and Bifurcaria bifurcata. Mar. Drugs 2017, 15, 360. [CrossRef] [PubMed]

46. Mabeau, S.; Fleurence, J. Seaweed in food products: Biochemical and nutritional aspects. Trends Food Sci. Technol. 1993, 4, 103-107. [CrossRef]

47. Ansari, A.A.; Ghanem, S.M. Growth attributes and biochemical composition of Padina pavonica (L.) from the Red Sea, in response to seasonal alterations of Tabuk, Saudi Arabia. Egypt. J. Aquat. Res. 2019, 45, 139-144. [CrossRef]

48. Adams, J.; Ross, A.á.; Anastasakis, K.; Hodgson, E.; Gallagher, J.; Jones, J.; Donnison, I. Seasonal variation in the chemical composition of the bioenergy feedstock Laminaria digitata for thermochemical conversion. Bioresour. Technol. 2011, 102, 226-234. [CrossRef] [PubMed]

49. Paiva, L.; Lima, E.; Neto, A.; Baptista, J. Seasonal variability of the biochemical composition and antioxidant properties of Fucus spiralis at two Azorean Islands. Mar. Drugs 2018, 16, 248. [CrossRef] [PubMed]

50. Etemadian, Y.; Shabanpour, B.; Ramzanpour, Z.; Shaviklo, A.R.; Kordjazi, M. Nutritional and Functional Properties of Two Dried Brown Seaweeds Sirophysalis trinodis and Polycladia myricab. J. Aquat. Food Prod. Technol. 2018, 27, 219-235. [CrossRef]

51. Neto, R.T.; Marçal, C.; Queirós, A.S.; Abreu, H.; Silva, A.M.S.; Cardoso, S.M. Screening of Ulva rigida, Gracilaria sp., Fucus vesiculosus and Saccharina latissima as Functional Ingredients. Int. J. Mol. Sci. 2018, 19, 2987. [CrossRef] [PubMed]

52. Rupérez, P. Mineral content of edible marine seaweeds. Food Chem. 2002, 79, 23-26. [CrossRef]

53. Darcy-Vrillon, B. Nutritional aspects of the developing use of marine macroalgae for the human food industry. Int. J. Food Sci. Nutr. (UK) 1993, 44, S23-S35.

54. Marinho, S.; Fonseca, P.; Carneiro, M.; Moreira, W. Seasonal variation in the chemical composition of two tropical seaweeds. Bioresour. Technol. 2006, 97, 2402-2406. [CrossRef]

55. Benjama, O.; Masniyom, P. Biochemical composition and physicochemical properties of two red seaweeds (Gracilaria fisheri and G. tenuistipitata) from the Pattani Bay in Southern Thailand. Sonklanakarin J. Sci. Technol. 2012, 34, 223-230.

56. Tabarsa, M.; Rezaei, M.; Ramezanpour, Z.; Waaland, J.R. Chemical compositions of the marine algae Gracilaria salicornia (Rhodophyta) and Ulva lactuca (Chlorophyta) as a potential food source. J. Sci. Food Agric. 2012, 92, 2500-2506. [CrossRef]

57. Schmid, M.; Guihéneuf, F.; Stengel, D.B. Fatty acid contents and profiles of 16 macroalgae collected from the Irish Coast at two seasons. J. Appl. Phycol. 2014, 26, 451-463. [CrossRef]

58. Galland-Irmouli, A.-V.; Fleurence, J.; Lamghari, R.; Luçon, M.; Rouxel, C.; Barbaroux, O.; Bronowicki, J.-P.; Villaume, C.; Guéant, J.-L. Nutritional value of proteins from edible seaweed Palmaria palmata (Dulse). J. Nutr. Biochem. 1999, 10, 353-359. [CrossRef]

59. Benjama, O.; Masniyom, P. Nutritional composition and physicochemical properties of two green seaweeds (Ulva pertusa and U. intestinalis) from the Pattani Bay in Southern Thailand. Sonklanakarin J. Sci. Technol. 2011, 33, 575-583.

60. Juneja, A.; Ceballos, R.; Murthy, G. Effects of environmental factors and nutrient availability on the biochemical composition of algae for biofuels production: A review. Energies 2013, 6, 4607-4638. [CrossRef]

61. Khairy, H.M.; El-Shafay, S.M. Seasonal variations in the biochemical composition of some common seaweed species from the coast of Abu Qir Bay, Alexandria, Egypt. Oceanologia 2013, 55, 435-452. [CrossRef]

62. Lahaye, M.; Jegou, D. Chemical and physical-chemical characteristics of dietary fibres from Ulva lactuca (L.) Thuret and Enteromorpha compressa (L.) Grev. J. Appl. Phycol. 1993, 5, 195. [CrossRef]

63. Rupérez, P.; Saura-Calixto, F. Dietary fibre and physicochemical properties of edible Spanish seaweeds. Eur. Food Res. Technol. 2001, 212, 349-354. [CrossRef] 
64. Kumari, P.; Bijo, A.; Mantri, V.A.; Reddy, C.; Jha, B. Fatty acid profiling of tropical marine macroalgae: An analysis from chemotaxonomic and nutritional perspectives. Phytochemistry 2013, 86, 44-56. [CrossRef]

65. Bhaskar, N.; Kinami, T.; Miyashita, K.; Park, S.-B.; Endo, Y.; Fujimoto, K. Occurrence of conjugated polyenoic fatty acids in seaweeds from the Indian Ocean. Z. Für Nat. C 2004, 59, 310-314. [CrossRef]

66. Khotimchenko, S.; Vaskovsky, V.; Titlyanova, T. Fatty acids of marine algae from the Pacific coast of North California. Bot. Mar. 2002, 45, 17-22. [CrossRef]

67. Francavilla, M.; Franchi, M.; Monteleone, M.; Caroppo, C. The red seaweed Gracilaria gracilis as a multi products source. Mar. Drugs 2013, 11, 3754-3776. [CrossRef]

68. Syad, A.N.; Shunmugiah, K.P.; Kasi, P.D. Seaweeds as nutritional supplements: Analysis of nutritional profile, physicochemical properties and proximate composition of G. acerosa and S. wightii. Biomed. Prev. Nutr. 2013, 3, 139-144. [CrossRef]

69. Cian, R.E.; Fajardo, M.A.; Alaiz, M.; Vioque, J.; González, R.J.; Drago, S.R. Chemical composition, nutritional and antioxidant properties of the red edible seaweed Porphyra columbina. Int. J. Food Sci. Nutr. 2014, 65, 299-305. [CrossRef] [PubMed]

70. Watson, R.R.; Zibadi, S. Bioactive Dietary Factors and Plant Extracts in Dermatology; Springer: Berlin, Germany, 2013.

71. Hong, D.D.; Hien, H.M.; Son, P.N. Seaweeds from Vietnam used for functional food, medicine and biofertilizer. J. Appl. Phycol. 2007, 19, 817-826. [CrossRef]

72. Cofrades, S.; López-Lopez, I.; Bravo, L.; Ruiz-Capillas, C.; Bastida, S.; Larrea, M.T.; Jiménez-Colmenero, F. Nutritional and antioxidant properties of different brown and red Spanish edible seaweeds. Food Sci. Technol. Int. 2010, 16, 361-370. [CrossRef] [PubMed]

73. Kolb, N.; Vallorani, L.; Stocchi, V. Chemical composition and evaluation of protein quality by amino acid score method of edible brown marine algae Arame (Eisenia bicyclis) and Hijiki (Hijikia fusiforme). Acta Aliment. 1999, 28, 213-222. [CrossRef]

74. FAO; WHO; UNU. Amino acid requirements of adults. In Protein and Amino Acids Requirements in Human Nutrition; World Health Organization: Rome, Italy, 2007; Volume 7, pp. 135-159.

75. Mišurcová, L.; Buňka, F.; Ambrožová, J.V.; Machů, L.; Samek, D.; Kráčmar, S. Amino acid composition of algal products and its contribution to RDI. Food Chem. 2014, 151, 120-125. [CrossRef] [PubMed]

76. Feng, Q.; Bo, F.; Lu, Y. Influence of copper ions and calcium ions on adsorption of CMC on chlorite. Trans. Nonferrous Met. Soc. China 2013, 23, 237-242. [CrossRef]

77. El-Din, N.S.; Mohamedein, L.; El-Moselhy, K.M. Seaweeds as bioindicators of heavy metals off a hot spot area on the Egyptian Mediterranean Coast during 2008-2010. Environ. Monit. Assess. 2014, 186, 5865-5881. [CrossRef]

78. Astorga-España, M.; Galdón, B.R.; Rodríguez, E.R.; Romero, C.D. Mineral and trace element concentrations in seaweeds from the sub-Antarctic ecoregion of Magallanes (Chile). J. Food Compos. Anal. 2015, 39, 69-76. [CrossRef]

79. Moreiras, O.; Carbajal, A.; Cabrera, L.; Cuadrado, C. Tablas de composición de alimentos (Food Composition Tables); Piramide Ediciones Sa: Madrid, Spanish, 2004.

80. Burtin, P. Nutritional value of seaweeds. Electron. J. Environ. Agric. Food Chem. 2003, 2, 498-503.

81. Rubio, C.; Napoleone, G.; Luis-González, G.; Gutiérrez, A.J.; González-Weller, D.; Hardisson, A.; Revert, C. Metals in edible seaweed. Chemosphere 2017, 173, 572-579. [CrossRef] [PubMed]

82. Arulkumar, A.; Nigariga, P.; Paramasivam, S.; Rajaram, R. Metals accumulation in edible marine algae collected from Thondi coast of Palk Bay, Southeastern India. Chemosphere 2019, 221, 856-862. [CrossRef] [PubMed]

83. Coultate, T.P. Food: The chemistry of its components; Royal Society of Chemistry: London, UK, 2009.

84. Flores, S.R.; Dobbs, J.; Dunn, M.A. Mineral nutrient content and iron bioavailability in common and Hawaiian seaweeds assessed by an in vitro digestion/Caco-2 cell model. J. Food Compos. Anal. 2015, 43, 185-193. [CrossRef]

85. Chen, Q.; Pan, X.-D.; Huang, B.-F.; Han, J.-L. Distribution of metals and metalloids in dried seaweeds and health risk to population in southeastern China. Sci. Rep. 2018, 8, 3578. [CrossRef] [PubMed]

86. FAO; WHO. Evaluation of Certain Food Additives and Contaminants: Sixty-Ninth Report of the Joint FAO/WHO Expert Committee on Food Additives; World Health Organization: Rome, Italy, 2009. 
87. FAO. WHO. Evaluation of Certain Food Additives and Contaminants: Seventy-Fourth Report of the Joint FAO/WHO Expert Committee on Food Additives; World Health Organization: Rome, Italy, 2011.

88. Larrea-Marín, M.; Pomares-Alfonso, M.; Gómez-Juaristi, M.; Sánchez-Muniz, F.; De La Rocha, S.R. Validation of an ICP-OES method for macro and trace element determination in Laminaria and Porphyra seaweeds from four different countries. J. Food Compos. Anal. 2010, 23, 814-820. [CrossRef]

89. Krewski, D.; Yokel, R.A.; Nieboer, E.; Borchelt, D.; Cohen, J.; Harry, J.; Kacew, S.; Lindsay, J.; Mahfouz, A.M.; Rondeau, V. Human health risk assessment for aluminium, aluminium oxide, and aluminium hydroxide. J. Toxicol. Environ. HealthPart. B 2007, 10,1-269. [CrossRef]

90. Singh, S.; Tripathi, D.K.; Singh, S.; Sharma, S.; Dubey, N.K.; Chauhan, D.K.; Vaculík, M. Toxicity of aluminium on various levels of plant cells and organism: A review. Environ. Exp. Bot. 2017, 137, 177-193. [CrossRef]

91. Ismail, A. A need for monitoring of heavy metals and organotin compounds in the east coast of Johor. In Research and information series of Malaysian coast of Malaysia marine ecosystem; Che Abdul Rahim, M., Masri, M.A., Zaidi, C.K., Norhayati, A., Eds.; Marine Ecosystem Research Centre UKM: Bangi, Malaysia, 2008; pp. 163-176.

92. Ismail, N.A.H.; Wee, S.Y.; Aris, A.Z. Bisphenol A and alkylphenols concentrations in selected mariculture fish species from Pulau Kukup, Johor, Malaysia. Mar. Pollut. Bull. 2018, 127, 536-540. [CrossRef]

93. Sidi, N.; Aris, A.Z.; Mohamat Yusuff, F.; Looi, L.J.; Mokhtar, N.F. Tape seagrass (Enhalus acoroides) as a bioindicator of trace metal contamination in Merambong shoal, Johor Strait, Malaysia. Mar. Pollut. Bull. 2018, 126, 113-118. [CrossRef]

94. Verstraeten, S.V.; Aimo, L.; Oteiza, P.I. Aluminium and lead: Molecular mechanisms of brain toxicity. Arch. Toxicol. 2008, 82, 789-802. [CrossRef] [PubMed]

95. Chamannejadian, A.; Sayyad, G.; Moezzi, A.; Jahangiri, A. Evaluation of estimated daily intake (EDI) of cadmium and lead for rice (Oryza sativa L.) in calcareous soils. Iran. J. Environ. Health Sci. Eng. 2013, 10, 28. [CrossRef] [PubMed]

96. Medeiros, R.J.; dos Santos, L.M.G.; Freire, A.S.; Santelli, R.E.; Braga, A.M.C.; Krauss, T.M.; Jacob, S.d.C. Determination of inorganic trace elements in edible marine fish from Rio de Janeiro State, Brazil. Food Control. 2012, 23, 535-541. [CrossRef]

97. Almela, C.; Clemente, M.J.; Vélez, D.; Montoro, R. Total arsenic, inorganic arsenic, lead and cadmium contents in edible seaweed sold in Spain. Food Chem. Toxicol. 2006, 44, 1901-1908. [CrossRef]

98. Yaich, H.; Garna, H.; Besbes, S.; Paquot, M.; Blecker, C.; Attia, H. Chemical composition and functional properties of Ulva lactuca seaweed collected in Tunisia. Food Chem. 2011, 128, 895-901. [CrossRef]

99. Wong, K.; Cheung, P.C. Nutritional evaluation of some subtropical red and green seaweeds: Part I-proximate composition, amino acid profiles and some physico-chemical properties. Food Chem. 2000, 71, 475-482. [CrossRef]

100. Carvalho, A.; Portela, M.; Sousa, M.; Martins, F.; Rocha, F.; Farias, D.; Feitosa, J. Physiological and physico-chemical characterization of dietary fibre from the green seaweed Ulva fasciata Delile. Braz. J. Biol. 2009, 69, 969-977. [CrossRef]

101. Fleury, N.; Lahaye, M. Chemical and physico-chemical characterisation of fibres from Laminaria digitata (kombu breton): A physiological approach. J. Sci. Food Agric. 1991, 55, 389-400. [CrossRef]

102. Pina-Pérez, M.C.; Rivas, A.; Martínez, A.; Rodrigo, D. Antimicrobial potential of macro and microalgae against pathogenic and spoilage microorganisms in food. Food Chem. 2017, 235, 34-44. [CrossRef]

103. Darah, I.; Tong, W.Y.; Nor-Afifah, S.; Nurul-Aili, Z.; Lim, S.H. Antimicrobial effects of Caulerpa sertularioides extract on foodborne diarrhea-caused bacteria. Eur Rev. Med. Pharm. Sci 2014, 18, 171-178.

104. Lima-Filho, J.V.M.; Carvalho, A.F.F.U.; Freitas, S.M.; Melo, V.M.M. Antibacterial activity of extracts of six macroalgae from the Northeastern Brazilian coast. Braz. J. Microbiol. 2002, 33, 311-314. [CrossRef]

105. Arulkumar, A.; Rosemary, T.; Paramasivam, S.; Rajendran, R.B. Phytochemical composition, in vitro antioxidant, antibacterial potential and GC-MS analysis of red seaweeds (Gracilaria corticata and Gracilaria edulis) from Palk Bay, India. Biocatal. Agric. Biotechnol. 2018, 15, 63-71. [CrossRef]

106. Deepak, P.; Sowmiya, R.; Kamaraj, C.; Josebin, M.P.D.; Aiswarya, D.; Balasubramani, G.; Amutha, V.; Perumal, P. Gc-Ms Profiling, Chemical Characterization, Antioxidant, Î '-Amylase And I '-Glucosidase Inhibition Of Selected Seaweeds From Southeast Coast Of India: An In Vitro Approach. J. Drug Deliv. Ther. 2018, 8, 60-72. [CrossRef] 
107. Narasimhan, M.K.; Pavithra, S.K.; Krishnan, V.; Chandrasekaran, M. In vitro analysis of antioxidant, antimicrobial and antiproliferative activity of Enteromorpha antenna, Enteromorpha linza and Gracilaria corticata extracts. Jundishapur J. Nat. Pharm. Prod. 2013, 8, 151-159. [CrossRef] [PubMed]

108. García-Bueno, N.; Decottignies, P.; Turpin, V.; Dumay, J.; Paillard, C.; Stiger-Pouvreau, V.; Kervarec, N.; Pouchus, Y.-F.; Marín-Atucha, A.A.; Fleurence, J. Seasonal antibacterial activity of two red seaweeds, Palmaria palmata and Grateloupia turuturu, on European abalone pathogen Vibrio harveyi. Aquat. Living Resour. 2014, 27, 83-89. [CrossRef]

109. Pérez, M.J.; Falqué, E.; Domínguez, H. Antimicrobial Action of Compounds from Marine Seaweed. Mar. Drugs 2016, 14, 52. [CrossRef] [PubMed]

110. Juneng, L.; Tangang, F.T. Level and source of predictability of seasonal rainfall anomalies in Malaysia using canonical correlation analysis. Int. J. Climatol. A J. R. Meteorol. Soc. 2008, 28, 1255-1267. [CrossRef]

111. Awang, H.; Daud, Z.; Hatta, M.Z.M. Hydrology properties and water quality assessment of the Sembrong Dam, Johor, Malaysia. Procedia-Soc. Behav. Sci. 2015, 195, 2868-2873. [CrossRef]

112. Wong, C.L.; Liew, J.; Yusop, Z.; Ismail, T.; Venneker, R.; Uhlenbrook, S. Rainfall Characteristics and Regionalization in Peninsular Malaysia Based on a High Resolution Gridded Data Set. Water 2016, 8, 500. [CrossRef]

113. Baharim, N.B.; Yusop, Z.; Yusoff, I.; Tahir, W.; Askari, M.; Othman, Z.; Abidin, M.R.Z. The relationship between heavy metals and trophic properties in Sembrong Lake, Johor. Sains Malays. 2016, 45, 43-53.

114. Malaysia, M.D. Climate change scenarios for Malaysia 2001-2099. Malaysia Meteorological Department: Petaling Jaya, Malaysia; p. 2009.

115. Daryabor, F.; Ooi, S.H.; Samah, A.A.; Akbari, A. Dynamics of the water circulations in the southern South China Sea and its seasonal transports. PLoS ONE 2016, 11, e0158415. [CrossRef] [PubMed]

116. Guest, J.R.; Baird, A.H.; Maynard, J.A.; Muttaqin, E.; Edwards, A.J.; Campbell, S.J.; Yewdall, K.; Affendi, Y.A.; Chou, L.M. Contrasting patterns of coral bleaching susceptibility in 2010 suggest an adaptive response to thermal stress. PLoS ONE 2012, 7, e33353. [CrossRef]

117. Daryabor, F.; Tangang, F.; Juneng, L. Simulation of southwest monsoon current circulation and temperature in the east coast of Peninsular Malaysia. Sains Malays. 2014, 43, 389-398.

118. Hurd, C.L.; Harrison, P.J.; Bischof, K.; Lobban, C.S. Seaweed Ecology and Physiology; Cambridge University Press: Cambridge, UK, 2014.

119. May-Lin, B.Y.; Ching-Lee, W. Seasonal growth rate of Sargassum species at Teluk Kemang, Port Dickson, Malaysia. J. Appl. Phycol. 2013, 25, 805-814. [CrossRef]

120. Kraufvelin, P.; Lindholm, A.; Pedersen, M.F.; Kirkerud, L.A.; Bonsdorff, E. Biomass, diversity and production of rocky shore macroalgae at two nutrient enrichment and wave action levels. Mar. Biol. 2010, 157, $29-47$. [CrossRef]

121. AOAC. Official methods of analysis of AOAC International; Association of Official Analytical Chemists: Rockville, MD, USA, 2000.

122. Tibbetts, S.M.; Milley, J.E.; Lall, S.P. Nutritional quality of some wild and cultivated seaweeds: Nutrient composition, total phenolic content and in vitro digestibility. J. Appl. Phycol. 2016, 28, 3575-3585. [CrossRef]

123. Zhou, A.Y.; Robertson, J.; Hamid, N.; Ma, Q.; Lu, J. Changes in total nitrogen and amino acid composition of New Zealand Undaria pinnatifida with growth, location and plant parts. Food Chem. 2015, 186, 319-325. [CrossRef] [PubMed]

124. Heems, D.; Luck, G.; Fraudeau, C.; Verette, E. Fully automated precolumn derivatization, on-line dialysis and high-performance liquid chromatographic analysis of amino acids in food, beverages and feedstuff. J. Chromatogr. A 1998, 798, 9-17. [CrossRef]

125. Gosch, B.J.; Magnusson, M.; Paul, N.A.; de Nys, R. Total lipid and fatty acid composition of seaweeds for the selection of species for oil-based biofuel and bioproducts. Gcb Bioenergy 2012, 4, 919-930. [CrossRef]

126. Petrović, M.; Kezić, N.; Bolanča, V. Optimization of the GC method for routine analysis of the fatty acid profile in several food samples. Food Chem. 2010, 122, 285-291. [CrossRef]

127. James, C.S. Analytical chemistry of foods; Springer Science \& Business Media: Berlin, Germany, 2013.

128. Carefoot, T. Calorimetry. Handbook of Phycological Methods. Ecological Field Methods: Macroalgae; Cambridge Univ. Press: Cambridge, UK, 1985; pp. 479-491.

129. McDermid, K.J.; Stuercke, B. Nutritional composition of edible Hawaiian seaweeds. J. Appl. Phycol. 2003, 15, 513-524. [CrossRef] 
130. Jaworska, G.; Pogoń, K.; Bernaś, E.; Skrzypczak, A.; Kapusta, I. Vitamins, phenolics and antioxidant activity of culinary prepared Suillus luteus (L.) Roussel mushroom. LWT-Food Sci. Technol. 2014, 59, 701-706. [CrossRef]

131. Pan, Y.; Wernberg, T.; de Bettignies, T.; Holmer, M.; Li, K.; Wu, J.; Lin, F.; Yu, Y.; Xu, J.; Zhou, C. Screening of seaweeds in the East China Sea as potential bio-monitors of heavy metals. Environ. Sci. Pollut. Res. 2018, 25, 16640-16651. [CrossRef] [PubMed]

132. Waheed, A.; Chohan, M.M.; Ahmed, D.; Ullah, N. The first report on the in vitro antimicrobial activities of extracts of leaves of Ehretia serrata. Saudi J. Biol. Sci. 2018. [CrossRef]

Sample Availability: Samples of the compounds are not available from the authors.

(C) 2019 by the authors. Licensee MDPI, Basel, Switzerland. This article is an open access article distributed under the terms and conditions of the Creative Commons Attribution (CC BY) license (http://creativecommons.org/licenses/by/4.0/). 